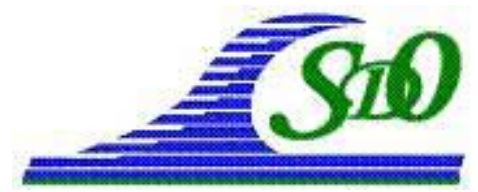

XI ${ }^{\text {èmes }}$ Journées Nationales Génie Côtier - Génie Civil

Les Sables d'Olonne, 22-25 juin 2010

DOI:10.5150/jngcgc.2010.082-O @ Editions Paralia CFL

disponible en ligne - http://www.paralia.fr - available online

\title{
Hydraulic performance, wave loading and response of ELASTOCOAST revetments and their foundations
}

\section{Hocine OUMERACI ${ }^{1}$, Tijl STAAL ${ }^{1}$, Saskia PFÖRTNER ${ }^{1}$, Gisa LUDWIGS ${ }^{1}$}

1. Technische Universität Braunschweig, Leichtweiß-Institute of Hydraulic Engineering and Water Resources, Beethovenstr. 51a, 38106 Braunschweig, and Coastal Research Centre (FZK), Hannover, Germany.

h.oumeraci@tu-bs.de

\begin{abstract}
:
ELASTOCOAST revetments are highly porous structures made of mineral aggregates (e.g. crushed stones) which are durably and elastically bonded by polyurethane (PU). Despite their numerous advantages as compared to conventional revetments and the large experience available from several pilot projects (e.g. in The Netherlands and Germany), physically-based design formulae to predict their hydraulic performance, wave loading and response are still lacking. Therefore, the present study aims at improving the understanding of the processes involved in the interaction between wave, revetment and foundation, based on large-scale model tests performed in the Coastal Research Centre (FZK), Hannover/Germany, and to provide formulae/diagrams for the prediction of (i) the hydraulic performance (wave reflection, wave run-up and rundown), (ii) the wave load on and beneath the revetment as well as in the subsoil for a wide range of wave conditions, including both impact and non-impact wave loads, (iii) the response of the revetment (flexural behaviour) and its foundation (pore pressure and effective stress).

The failure of one of the three ELASTOCOAST revetment model alternatives A, B and $\mathrm{C}$ tested at prototype scale is also analysed on the basis of the data simultaneously recorded by more than 80 transducers synchronously connected to two video cameras. As a result, it is shown that the weakest ELASTOCOAST alternative failed due to transient liquefaction of the sand core beneath the revetment while another ELASTOCOAST alternative, synchronously tested under exactly the same wave conditions, did not fail. Generic implications are then drawn from these results for the design of bonded permeable revetments subject to water waves.

Finally, a brief outlook is provided on the planned future research directed towards numerical modelling and the incorporation of these results in a design manual for polyurethane bonded aggregate (PBA) revetments.
\end{abstract}

Keywords:

Bonded permeable revetments - Wave impact loads - Wave-structure-subsoil interaction - Wave-induced pore pressure - Transient soil liquefaction 


\section{Introduction}

"ELASTOCOAST" has been introduced in 2004 for the shore protection of Hamburger Hallig as a new type of highly porous revetment made of mineral aggregates such as crushed stones which are durably and elastically bonded by polyurethane (PU). Since then ELASTOCOAST has been applied at 15 further coastal sites in Germany, four pilot sites in The Netherlands, four in France, two in the UK and one in Canada (see www.elastogran.de).

As compared to their conventional counterparts, ELASTOCOAST revetments have many advantages. Wave run-up, and thus also the required height of the defence structure, can be substantially reduced as compared to smooth impermeable revetments. Moreover, wave reflection which may affect both navigation and sea bed stability is also reduced. The high porosity combined with the durable elastic bonding may result in a much smaller revetment thickness required to resist the design wave load. The ecological advantages have also been illustrated by a recent field and laboratory study (LOCK, 2008). Despite all these advantages and the large field experience available at many pilot sites, the physical processes associated with the hydraulic performance, the wave loading and the response of the ELASTOCOAST revetment and its foundation are still not well-understood. Consequently, physically-based design formulae are still lacking.

With this background, systematic studies, mainly based on large-scale model testing in the Large Wave Flume (GWK) of the Coastal Research Centre (FZK) of both Universities Braunschweig and Hannover, have been conducted in 2009 with the following objectives:

(i) Improve the understanding of the physical processes involved in the interaction of the ELASTOCOAST revetment with the waves and the underlying sand core.

(ii) Develop prediction formulae for the hydraulic performance, including wave reflection, wave run-up and wave run-down.

(iii) Develop prediction formulae for the wave loads on and beneath the revetment as well as in the subsoil for a wide range of wave conditions, including both impact and non-impact loads.

(iv) Develop formulae for the prediction of the response of the revetment (bending) and its foundation (wave-induced pore pressure).

(v) Reproduce and analyse possible failure mechanisms such as those due to transient soil liquefaction beneath the revetment.

The primary objective of this paper is to provide a brief summary and discussion of the results related to the five aforementioned aspects. Implications of these results are then drawn for the design of bonded permeable revetment subject to water waves, and finally a brief outlook is given on (i) the planned future research which will be mainly directed towards further improving the understanding of the most relevant failure mechanisms 


\section{XI ìmes Journées Nationales Génie Côtier-Génie Civil}

Les Sables d'Olonne, 22-25 juin 2010

and numerical modelling and on (ii) the planned incorporation of these results in a design manual for polyurethane bonded aggregate revetments.

\section{Model set-up, measuring techniques and testing programme}

\subsection{Model set-up}

The experiments were performed in the Large Wave Flume (GWK) of Hannover, Germany. It is about $300 \mathrm{~m}$ long and $5 \mathrm{~m}$ wide. The depth of $7 \mathrm{~m}$ allows water levels up to $5 \mathrm{~m}$. Regular waves with wave heights up to $2 \mathrm{~m}$ and wave spectra with significant wave heights up to $1.3 \mathrm{~m}$ can be generated (non-breaking waves). Moreover, solitary waves up to about $1.0 \mathrm{~m}$ and "freak" waves (wave focussing) up to $2.5 \mathrm{~m}$ can also be generated. The wave generator has an active absorption control, thus providing constant input wave parameters over longer test durations. A cross section and a section along the flume with the ELASTOCOAST revetment (slope 1:3) are given in figure 1.

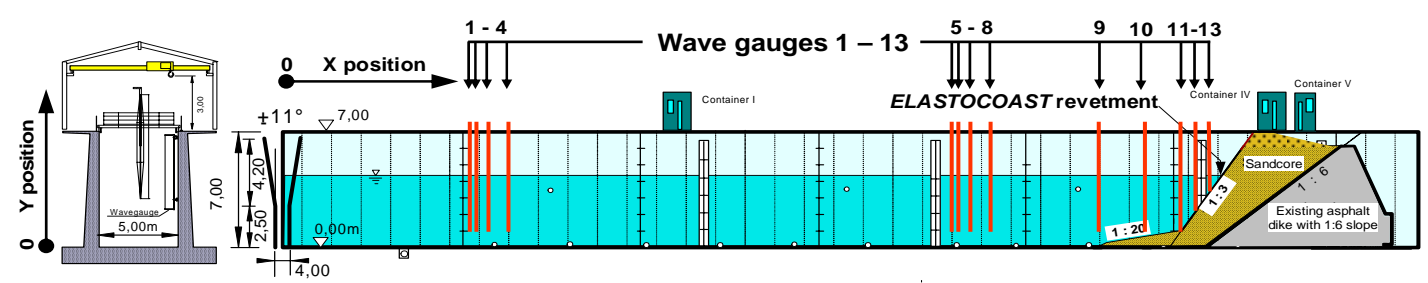

Figure 1. ELASTOCOAST revetment in GWK and location of wave gauges.

The embankment was built of sand with grain size $D_{50}=0.34 \mathrm{~mm}, D_{10}=0.18 \mathrm{~mm}$ and $\mathrm{U}=\mathrm{D}_{60} / \mathrm{D}_{10}=2.11$. The foreshore of the ELASTOCOAST revetment (slope of 1:3) is a sand bed with a slope of $1: 20$. The toe of the revetment is located $1.0 \mathrm{~m}$ above the flume bottom while the crest of the revetment is extended up to $6.70 \mathrm{~m}$ near the top edge of the flume which is at $7.00 \mathrm{~m}$ (figure 1).

In a first phase, the model set-up consists of two alternative revetments. The two model alternatives $\mathrm{A}$ and $\mathrm{B}$ were built together side by side, each covering half of the wave flume width $(2 \times 2.5 \mathrm{~m})$ and tested simultaneously under the same incident wave conditions (figure 2).

(a) Model A

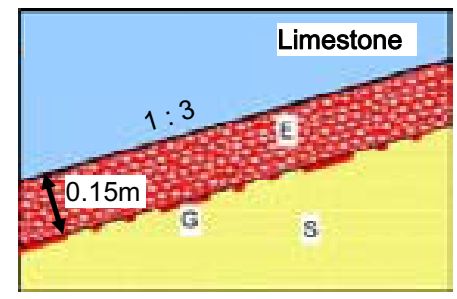

(b) Model B

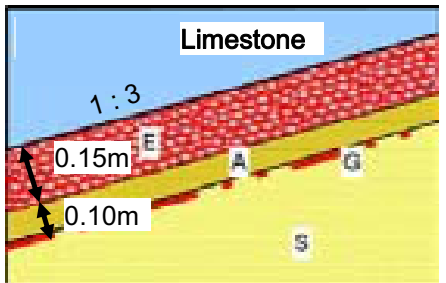

$\mathrm{E}=$ ELASTOCOAST $0.15 \mathrm{~m}$

(crushed Limestone 20/40 mm)

$\mathrm{A}=$ Filter layer $0.10 \mathrm{~m}$

(crushed Limestone 20/40 mm)

$\mathrm{G}=$ Geotextile (Terrafix 609)

$\mathrm{S}=$ Sand foundation

$\left(D_{50}=0.34 \mathrm{~mm}, \mathrm{U}=\mathrm{D}_{60} / \mathrm{D}_{10}=2.11\right)$

Figure 2. Model Alternatives $A$ and $B$. 
Both model alternatives have an ELASTOCOAST layer of the same thickness $(d=0.15 \mathrm{~m})$ made of the same crushed limestones $(20 / 40 \mathrm{~mm})$ bonded together by the same Polyurethane. The difference between the two models consists only in the layer beneath the ELASTOCOAST (figures $2 \mathrm{a} \& 2 \mathrm{~b}$ ). While for Model Alternative A the ELASTOCOAST lies directly on a geotextile, for Model Alternative B it lies on a gravel filter layer with a thickness of $0.10 \mathrm{~m}$ using the same crushed limestone material $(20 / 40 \mathrm{~mm})$ as for the ELASTOCOAST revetment. The gravel filter is inserted between the ELASTOCOAST layer and the geotextile lying on the sand slope (figure 2b). The two alternatives are separated by a thin wall made of water resistant plywood (figure 4). After the damage of Model Alternative A which was built across one half width of the flume, the damaged revetment was completely removed and replaced by a third Model Alternative C (figure 3). This alternative is similar to Model Alternatives A and B, but the ELASTOCOAST layer consists of crushed granite stones $(16 / 36 \mathrm{~mm})$ and the under layer made of the same stone is twice of thick $(0.20 \mathrm{~m})$ as in Model Alternative B (figures $2 \& 3$ ).

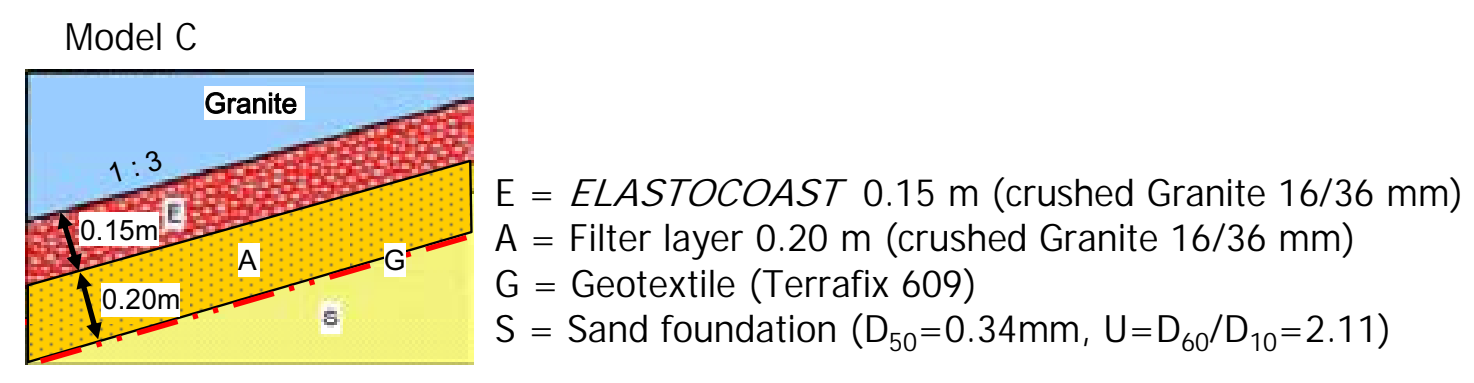

Figure 3. Model Alternative C (built after failure of Model Alternative A).

The hydraulic properties of the crushed stone material used for the ELASTOCOAST and the under layer can be approximately estimated from the data provided in MUTTRAY, (2001) where similar crushed stones with $\mathrm{D}_{50}=34 \mathrm{~mm}$ in the core of rubble mound breakwater tested in GWK were used. Porosity $n$ was determined to $n=0.39$, FORCHHEIMER coefficients $a$ and $b$ to $a=0.89$ and $b=23.0$, and inertia coefficient $c$ to $\mathrm{c}=0.41$.

\subsection{Measuring and observation techniques}

A total of 86 measuring devices and two digital video cameras connected to a data acquisition system have been installed (figure 4). As a result, a total of 88 measuring channels are obtained consisting of 15 wave gauges, 4 wave run-up gauges, 10 gauges and two ultrasonic sensors for the water layer thickness in the swash zone, 48 pressure transducers, 2 inductive displacement meters, 2 accelerometers and 2 control signals. As illustrated in figure 4, the same devices are placed at the same location for both model alternatives built side by side in the wave flume. All measuring devices and the two 
video cameras are fully synchronised. The locations of the measuring and observation devices are displayed in figure 4 .

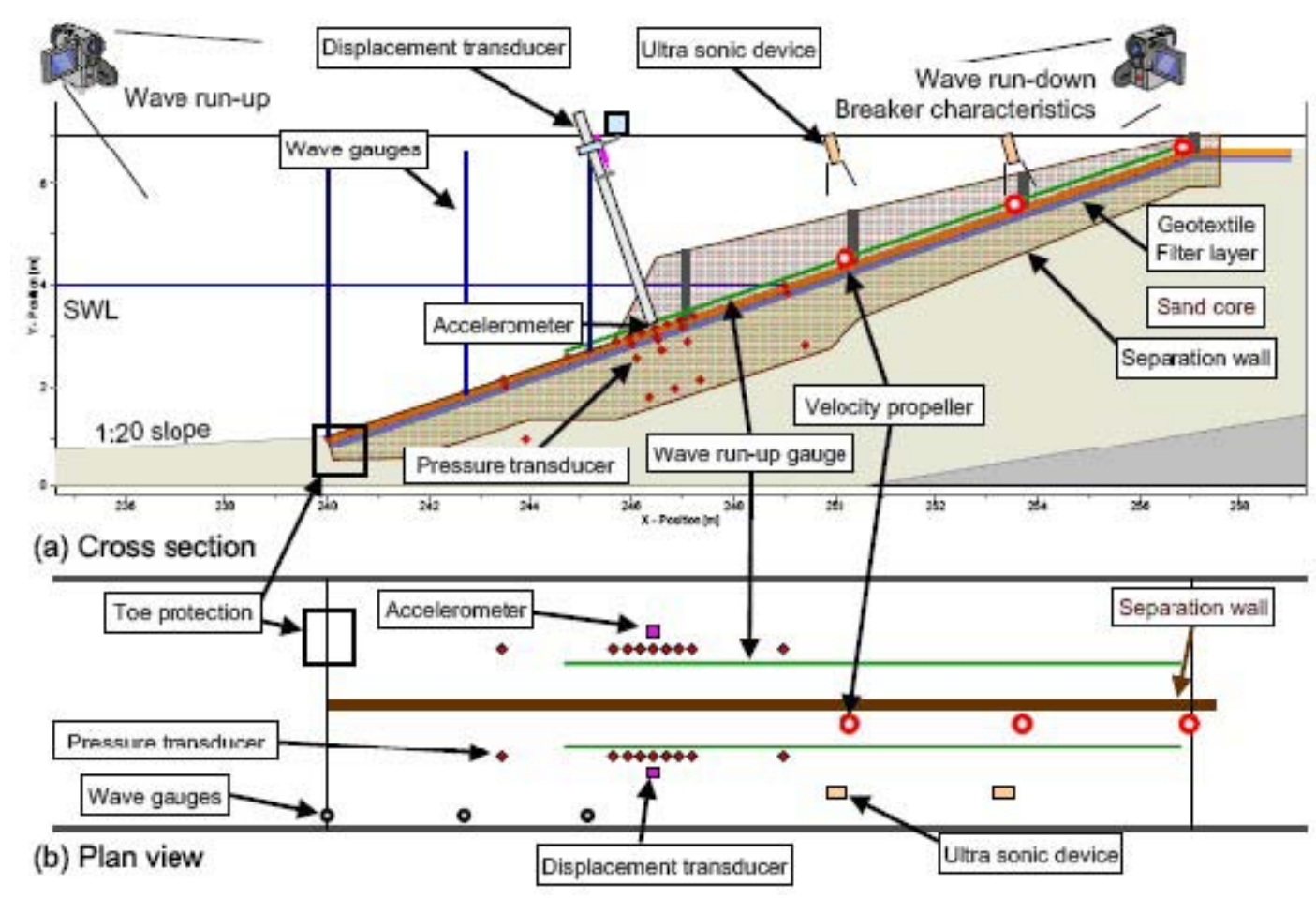

Figure 4. Measuring and observation devices at and beneath the revetment.

\subsection{Testing programme}

More than 35 tests with regular waves $(\mathrm{H}=0.2-1.3 \mathrm{~m}, \mathrm{~T}=3-8 \mathrm{~s}, \mathrm{~h}=3.4 .-4.2 \mathrm{~m}$, 100 waves/test $)$ and more than 40 tests with irregular waves $\left(H_{s}=0.2-1.1 \mathrm{~m}, \mathrm{~T}_{\mathrm{p}}=3-8 \mathrm{~s}\right.$, $\mathrm{h}=3.4-4.2 \mathrm{~m}, 1000$ waves/test) were performed, including few tests with solitary waves and "freak waves". Since the main goal of the study is to come up with empirical formulae/diagrams for design purposes, the main focus was put on the analysis of the experiments with wave spectra. Therefore, the results and formulae described in this paper are mainly based on the irregular wave tests (For comparison with regular wave tests see OUMERACI et al. (2009c)).

\section{Hydraulic Performance}

Wave reflection from coastal structures may severely affect the structure stability by increasing sea bed scour. It may also increase the erosion of the foreshore and of the neighbouring coastal stretches. Reflection coefficient $\mathrm{C}_{\mathrm{r}}$, obtained from the analysis of the tests, ranges from $\mathrm{C}_{\mathrm{r}}=0.26$ to $\mathrm{C}_{\mathrm{r}}=0.75$.

Several prediction formulae for the reflection coefficient have been proposed in the past (ZANUTTIGH \& VAN DER MEER, 2006). A comparative analysis of the 
uncertainties associated with 12 prediction formulae was performed previously by OUMERACI \& MUTTRAY (2001), showing coefficients of variation from 10 to $140 \%$. Amongst the existing models, the formula by SEELIG (1983) was found to be most widely used and is associated with the lowest uncertainties:

$$
\mathrm{C}_{\mathrm{r}}=\frac{\mathrm{a} \cdot \xi_{0}^{2}}{\mathrm{~b}+\xi_{0}^{2}}
$$

where:

$\xi_{0} \quad[-] \quad$ surf similarity parameter $\xi_{0}=\frac{\tan \alpha}{\sqrt{\mathrm{H}_{0} / \mathrm{L}_{0}}}$

$\mathrm{a}, \mathrm{b}[-]$ structure parameter, depending on the permeability, roughness, geometry and water depth conditions

Plotting reflection coefficient $\mathrm{C}_{\mathrm{r}}$ against surf similarity parameter $\xi_{\mathrm{m}-1,0}$, calculated using characteristic wave period $T_{m-1,0}$ and characteristic wave height $H_{m 0}$ the result in figure 5 is obtained.

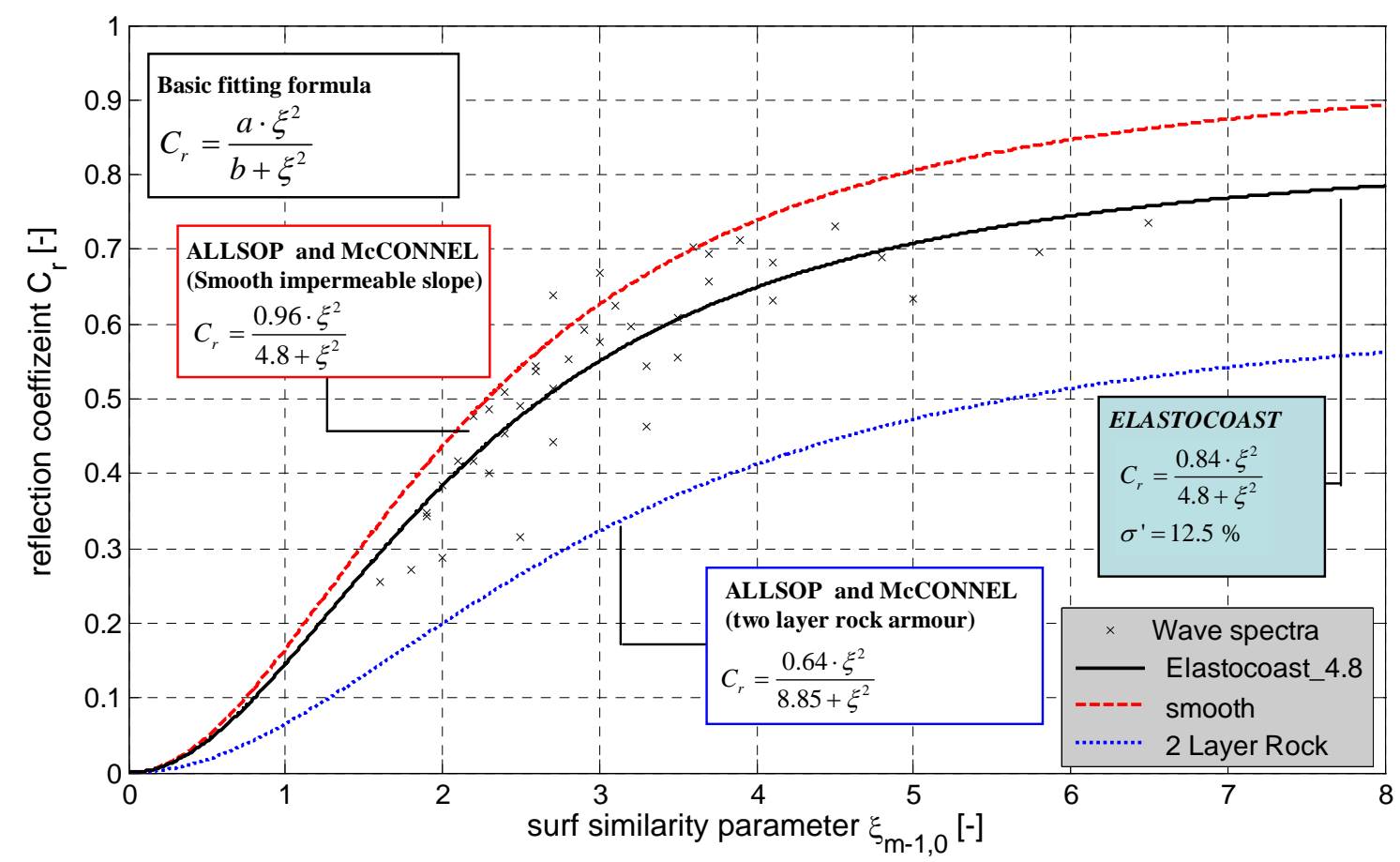

Figure 5. Reflection coefficient $C_{r}$ plotted against surf similarity parameter $\xi_{m-1,0}$.

The reflection coefficient of the ELASTOCOAST revetment remains smaller than that of a smooth impermeable slope. For a two layer rock armour it is much smaller than the reflection coefficient for the ELASTOCOAST revetment. Hence, reflection coefficient $C_{r}$ for the ELASTOCOAST revetment investigated in this study can be estimated with Equation (3), associated with a coefficient of variation $\sigma^{\prime}=12.5 \%$ : 


$$
\mathrm{C}_{\mathrm{r}}=\frac{0.84 \cdot \xi^{2}}{4.8+\xi^{2}} \text {. }
$$

Further analysis has shown that the effect of the wave period is much more important than considered in surf similarity parameter $\xi_{\mathrm{m}-1,0}$ (OUMERACI et al., 2009c). Therefore, future research should be directed to identify a governing parameter as a substitute for $\xi_{\mathrm{m}-1,0}$ which better accounts for the effect of wave period $\mathrm{T}_{\mathrm{m}-1,0}$.

Wave run-up $\mathrm{R}_{\mathrm{u}}$ is defined as the maximum elevation from still water level (SWL) to the point to which the water surface rises on the seaward face of the revetment. $R_{u}$ is important to determine the required height of the structure. Generally, the run-up level exceeded by $2 \%$ of the incident waves $\left(\mathrm{R}_{\mathrm{u} 2 \%}\right)$ is commonly used for design purpose. $\mathrm{R}_{\mathrm{u} 2 \%}$ generally depends on the wave height, the surf similarity parameter, the geometry and surface roughness of the slope, and on the permeability of the structure. For porous structures with a rough slope such as ELASTOCOAST revetments, most of the energy dissipation takes place on and within the revetment. A literature study has shown that the run-up model for the ELASTOCOAST revetment for which the best fit is obtained with the measured data is the one proposed by the EurOtop manual for smooth impermeable slopes (EUROTOP, 2007). Based on this model, run-up formulae were determined for the ELASTOCOAST revetment with a coefficient of variation $\sigma$ ' of about $16 \%$ (figure 6):

$$
\frac{\mathrm{R}_{\mathrm{u} 2 \%}}{\mathrm{H}_{\mathrm{m} 0}}=0.54 \cdot\left[1.65 \cdot \xi_{\mathrm{m}-1,0}\right] \text { for } \xi<2.7
$$

with a maximum of

$$
\frac{\mathrm{R}_{\mathrm{u} 2 \%}}{\mathrm{H}_{\mathrm{m} 0}}=0.77 \cdot\left[4.0-\frac{1.5}{\sqrt{\xi_{\mathrm{m}-1,0}}}\right] \text { for } \xi \geq 2.7
$$

Wave run-down $\mathrm{R}_{\mathrm{d}}$ is defined as the lowest elevation from still water level (SWL) that can be reached by the down rushing wave on the seaward face of the revetment. $R_{d}$ is important in defining the required elevation of the revetment under SWL. Run down 


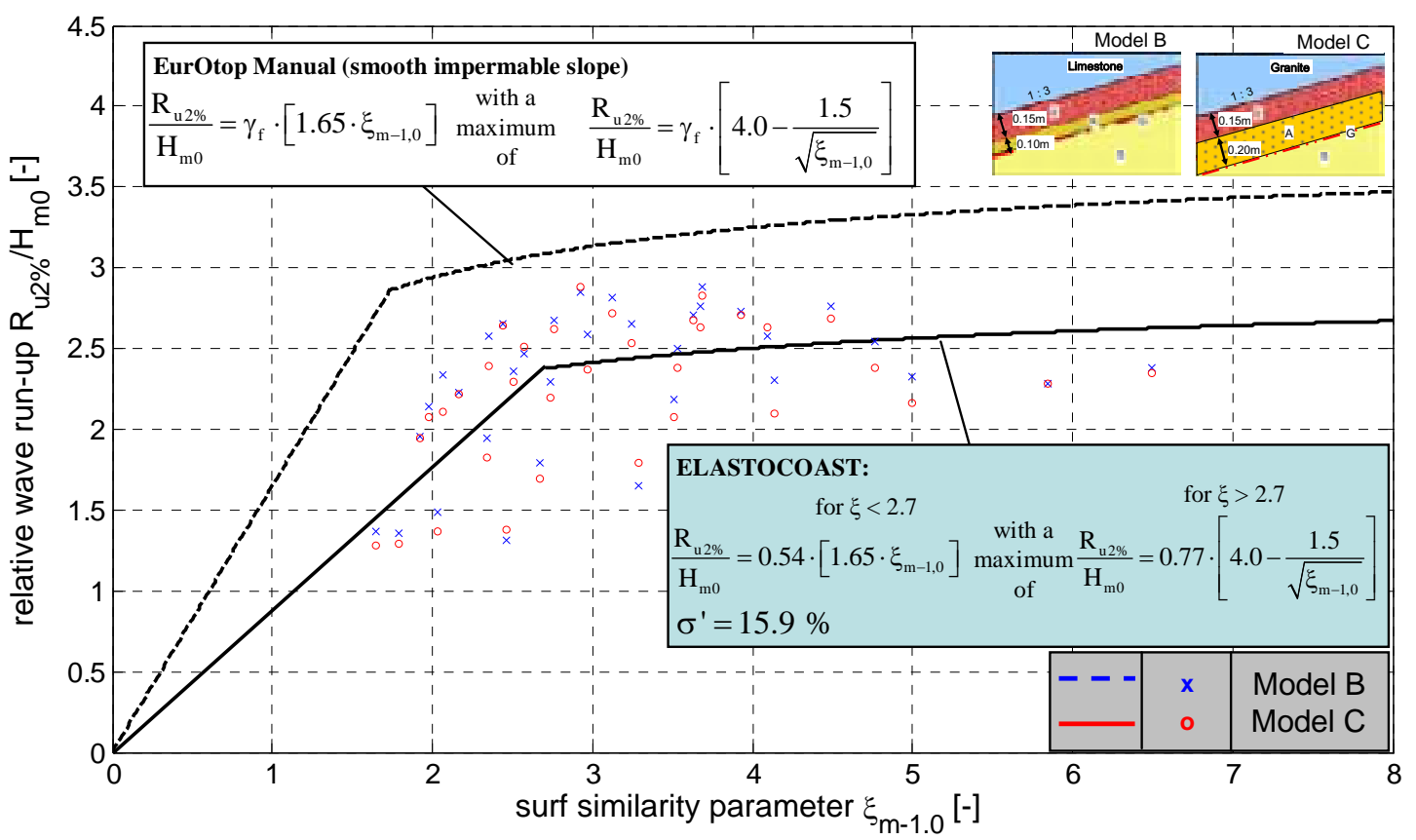

Figure 6. Wave run-up $R_{u 2 \%}$ for irregular waves.

is also important for the uplift pressure on the revetment which results from the internal water level which is generally higher than the external water level during the down rush process. The run-down level exceeded by $2 \%$ of the incident waves $\left(\mathrm{R}_{\mathrm{d} 2 \%}\right)$ is commonly used for design purpose. $\mathrm{R}_{\mathrm{d} 2} \%$ generally depends on the wave height, the surf similarity parameter, the geometry and surface roughness of the slope, and on the permeability of the structure.

A literature study has shown that the run-down models for the ELASTOCOAST revetment for which the best fit is obtained with the measured data are (i) those proposed by CEM-PartVI (USACE, 2002) for a smooth revetment of placed concrete blocks and (ii) the model developed for smooth impermeable slopes (PILARCZYK et al., 1995).

Based on these models, the following run-down formula was determined for the ELASTOCOAST revetment (figure 7):

$\frac{\mathrm{R}_{\mathrm{d} 2 \%}}{\mathrm{H}_{\mathrm{m} 0}}=-0.42 \cdot \xi_{\mathrm{m}-1.0}+0.17$ for $\xi_{\mathrm{m}-1.0}<5.7$

with a maximum of:

$\frac{\mathrm{R}_{\mathrm{d} 2 \%}}{\mathrm{H}_{\mathrm{m} 0}}=-2.25$ for $\xi_{\mathrm{m}-1.0} \geq 5.7$

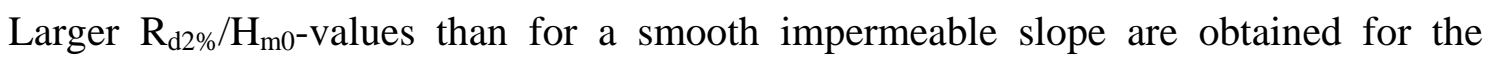
ELASTOCOAST revetment. The difference is significant (up to 66\%) for large $\xi_{\mathrm{m}-1,0^{-}}$ values $\left(\xi_{\mathrm{m}-1,0}>6\right)$. However, smaller run-down values than for a smooth revetment of placed concrete blocks as reported in CEM (USACE, 2002) are obtained (figure 7). 


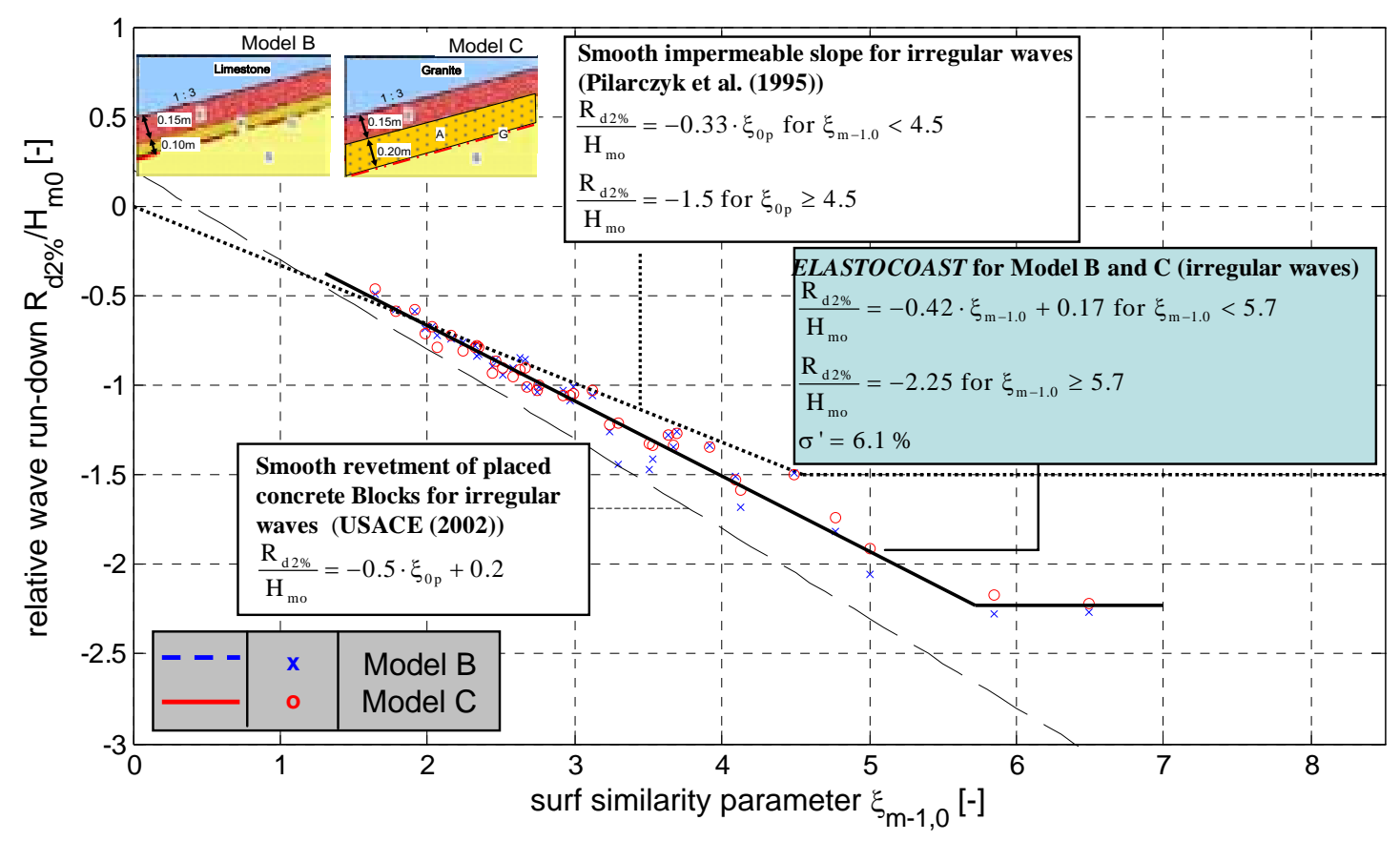

Figure 7. Wave run-down $R_{d 2}$ for irregular waves.

\section{Wave pressure on and just beneath the revetment}

The most extensive part of the analysis is dedicated to the analysis of the pressure induced by the waves on and just beneath the revetment This includes a wave load classification and a parameterization in both space and time as well as the development of empirical formulae for the prediction of the parameters which are needed to fully describe the wave load.

\section{Wave load classification}

All measured pressures refer to the pressure induced by wave motion only, excluding hydrostatic pressure resulting from water depth $\mathrm{h}$ at still water level (SWL); i.e. before each test (still water level and no waves!) all pressure transducers are set to $p=0$, though hydrostatic pressure $\mathrm{p}_{0}(\mathrm{x})$ at location $\mathrm{x}$ from the shoreline $(\mathrm{x}=0)$ depends on the local water depth $h(x): p_{0}(x)=\rho \cdot g \cdot h(x)$. Thus, the reference pressure for all measured pressure values is $p_{0}(x)=0$ at all pressure transducers, irrespective of their locations in the model.

Depending on the surf similarity parameter $\xi_{\mathrm{m}-1,0}$ tested $\left(\xi_{\mathrm{m}-1,0}=1.6-6.6\right)$ a wave load classification is proposed in figure 8 , including impact load $\left(\xi_{\mathrm{m}-1,0}=1.6-2.5\right)$, nonimpact load $\left(\xi_{\mathrm{m}-1,0}>2.9\right)$ and a transition zone $\left(\xi_{\mathrm{m}-1,0}=1.6-2.5\right)$. 


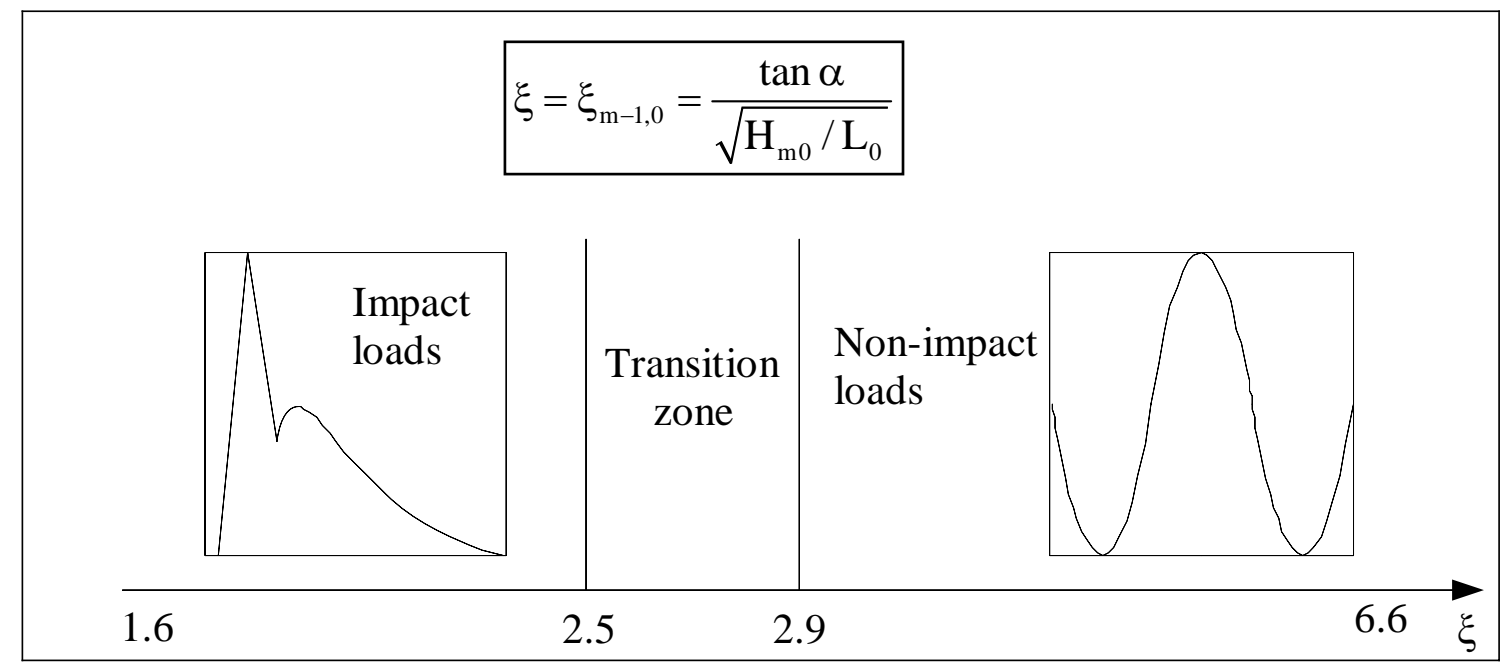

Figure 8. Wave load classification as a function of surf similarity parameter $\xi_{m-1,0}$.

Parameterisation of impact and non-impact load

Impact load induced by waves plunging on the slope is characterised by a pressure peak of short duration (impact component) which is super-imposed by a quasi-static component varying cyclicly with the wave motion on the slope (wave period T). This is shown in figure 9 which also depicts the definition of the maximum pressure $p_{\max }$ for the impact load component and $\mathrm{p}_{\mathrm{stat}, \text { imp }}$ for the quasi static load component.

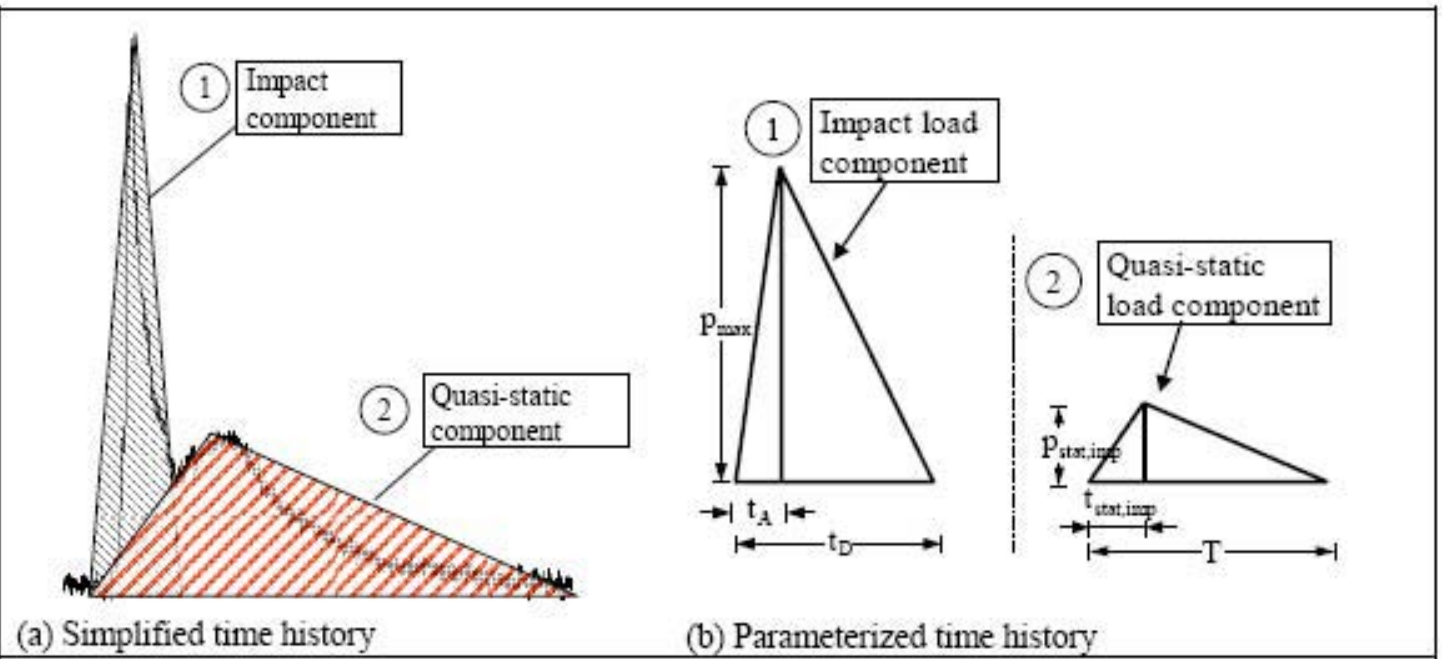

Figure 9. Parameterization in time of impact loads.

The pressure distribution on the revetment surface is described by five pairs of parameters $\left(\mathrm{p}_{\mathrm{i}}, \mathrm{z}_{\mathrm{i}}\right)$; each pair provides the magnitude of the local pressure $\mathrm{p}_{\mathrm{i}}$ at elevation $z_{i}$ beneath SWL. It is meaningful to relate the pressure $p_{i}$ at different locations along the slope to the maximum peak pressure $\mathrm{p}_{\max }$, and the associated elevation $\mathrm{z}_{\mathrm{i}}$ to the location of the maximum pressure $\mathrm{z}_{\mathrm{pmax}}$, thus providing five pairs of dimensionless parameters as 
shown in figure 10a. Similarly, the wave pressure distributions just beneath the revetment is described by parameter pairs $\left(\mathrm{p}_{\mathrm{i}}^{\prime}, \mathrm{z}_{\mathrm{i}}^{\prime}\right)$, each pair providing the magnitude of the local pressure $\mathrm{p}_{\mathrm{i}}^{\prime}$, at point $\mathrm{i}^{\prime}$ and the associated elevation $\mathrm{z}_{\mathrm{i}}^{\prime}$ beneath SWL. Relating the local pressure $\mathrm{p}_{i}^{\prime}$ to $\mathrm{p}_{\max }$ (on the revetment surface) and the associated elevation $\mathrm{z}_{\mathrm{i}}^{\prime}$ to $\mathrm{z}_{\mathrm{pmax}}$ will provide four pairs of dimensionless parameters as shown in figure $10 \mathrm{~b}$.

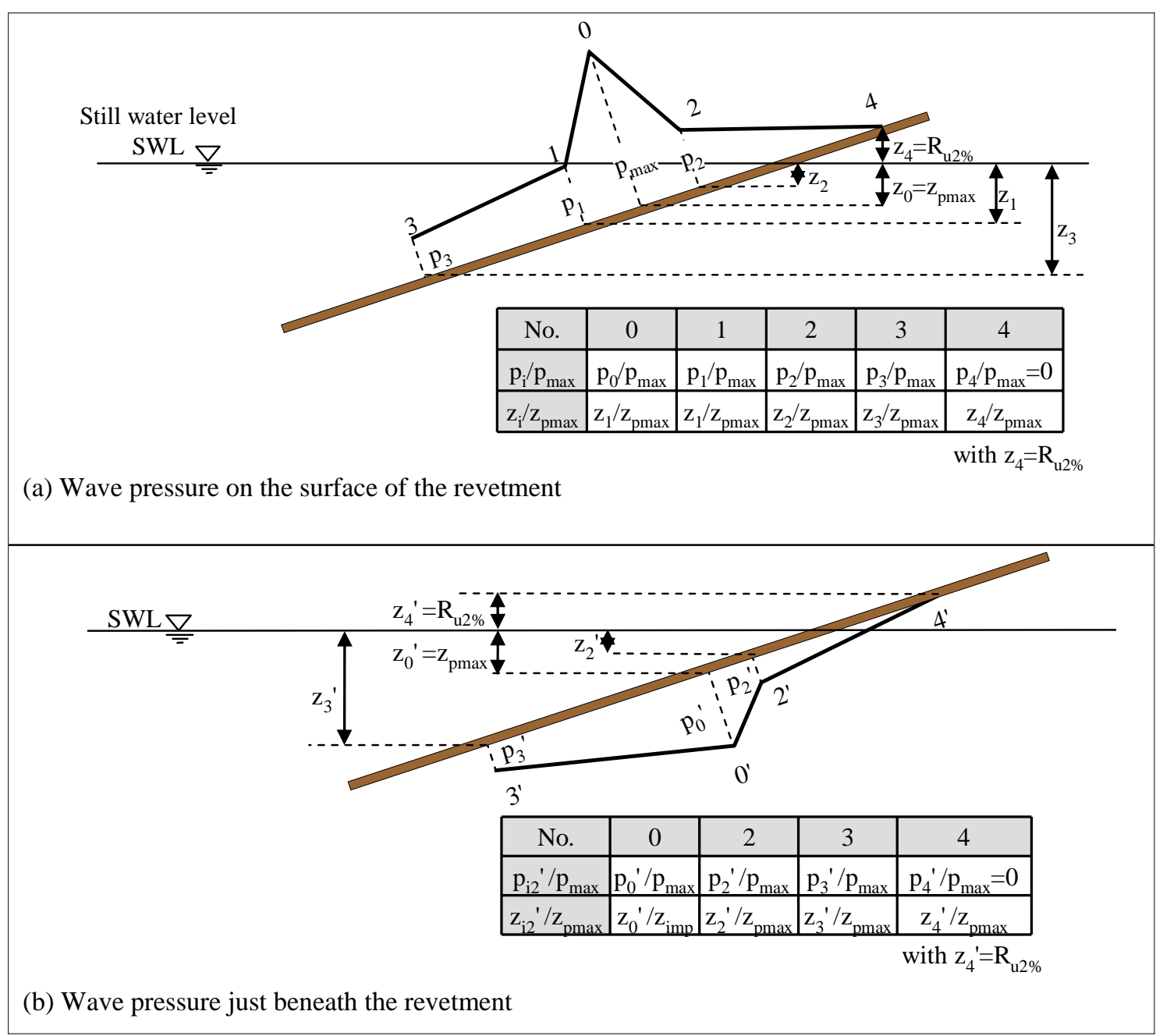

Figure 10. Parameterization of wave pressure distributions on and beneath the revetment for impact load.

Non-impact load induced by waves surging on the slope is characterized by pressure cyclicly varying with the wave motion, and is therefore similar to the quasi-static load component following the impact load component (figure 9b). This is shown in figure 11, which also depicts the pressure and the time related parameters. The static load is idealised by a trapezium, so that the entire pressure history for non-impact load can be parameterized as illustrated by figure 11b: the quasi-static load is described by 
four parameters: peak pressure $p_{\max }$ or $p_{\text {stat }}$, rise time $t_{\text {stat, }, 1}$, time till pressure decrease $t_{\text {stat }, 2}$ and load duration $T$ which corresponds to the period of the incident waves.

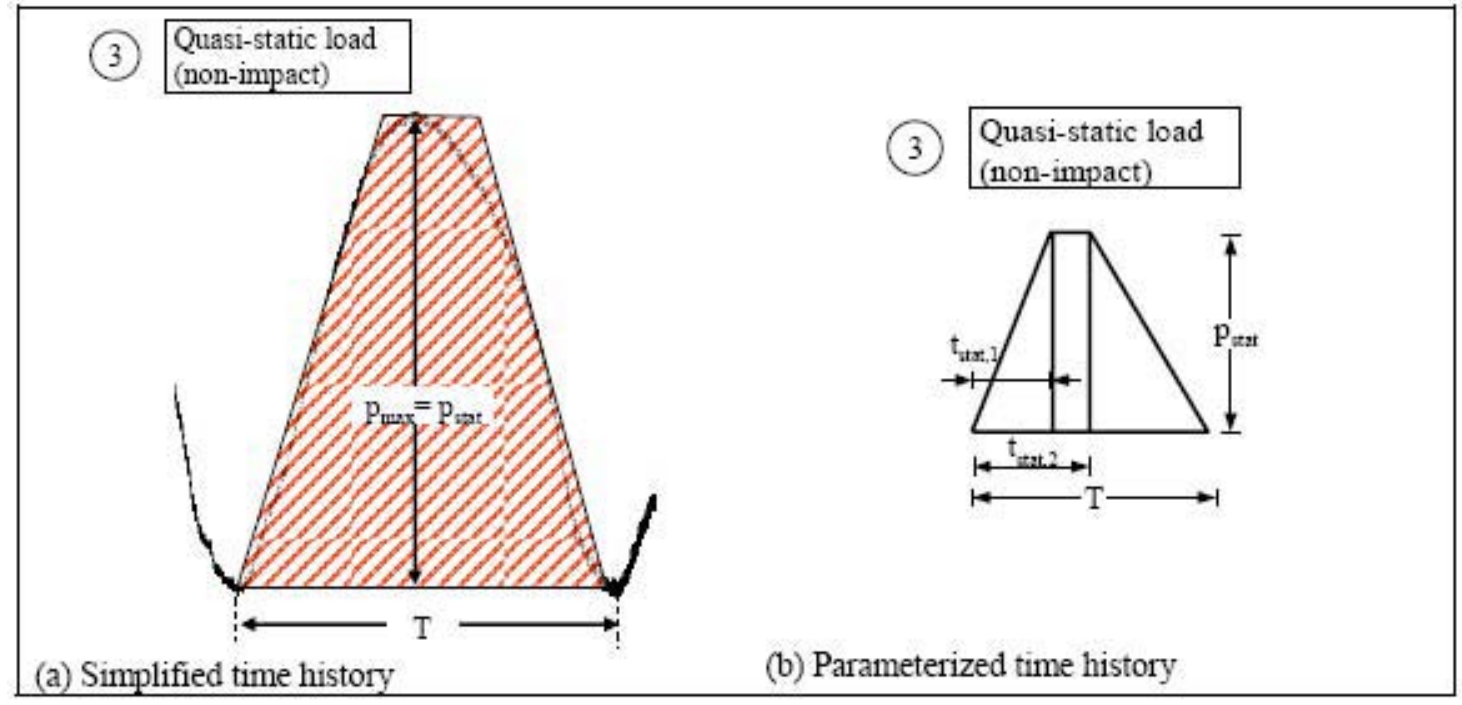

Figure 11. Parameterisation in time of non-impact load.

The same parameterization applies for the non-impact load beneath the revetment. The parameterization of the non-impact load in space is illustrated in figure 12a,b for the pressure on and just beneath the revetment.

The pressure distribution on the revetment surface is described by three pairs of parameters $\left(\mathrm{p}_{\mathrm{i}}, \mathrm{z}_{\mathrm{i}}\right)$, each pair providing the magnitude of the local pressure $\mathrm{p}_{\mathrm{i}}$ at elevation $z_{i}$ beneath the SWL. It is meaningful to relate the pressure $p_{i}$ to the maximum peak pressure $p_{\max }$ and the elevation $z_{i}$ to the location of the maximum pressure $z_{p m a x}$, thus providing three pairs of dimensionless parameters as shown in figure 12a. Similarly, the wave pressure distribution just beneath the revetment is described by pairs of parameters $\left(\mathrm{p}_{\mathrm{i}}{ }^{\prime}, \mathrm{z}_{\mathrm{i}}{ }^{\prime}\right)$, each pair providing the magnitude of the local pressure $\mathrm{p}_{\mathrm{i}}$,' at point $i^{\prime}$ and the associated elevation $z_{i}^{\prime}$ beneath SWL. Relating the local pressure $\mathrm{p}_{i}^{\prime}$ to $\mathrm{p}_{\max }$ (on the revetment surface) and the associated elevation $\mathrm{z}_{\mathrm{i}}^{\prime}$ to $\mathrm{z}_{\mathrm{pmax}}$ will also provide three pairs of dimensionless parameters as shown in figure $12 \mathrm{~b}$.

Peak pressure $\mathrm{p}_{\max }$ and its location $\mathrm{z}_{\mathrm{pmax}}$ along the slope, represent the key parameters since both are used as reference parameters for the calculation of the other related parameters which are required to calculate the wave pressure distribution on and just beneath the revetment. Therefore, prediction formulae for $\mathrm{p}_{\max }$ and $\mathrm{z}_{\mathrm{pmax}}$ are needed first. 


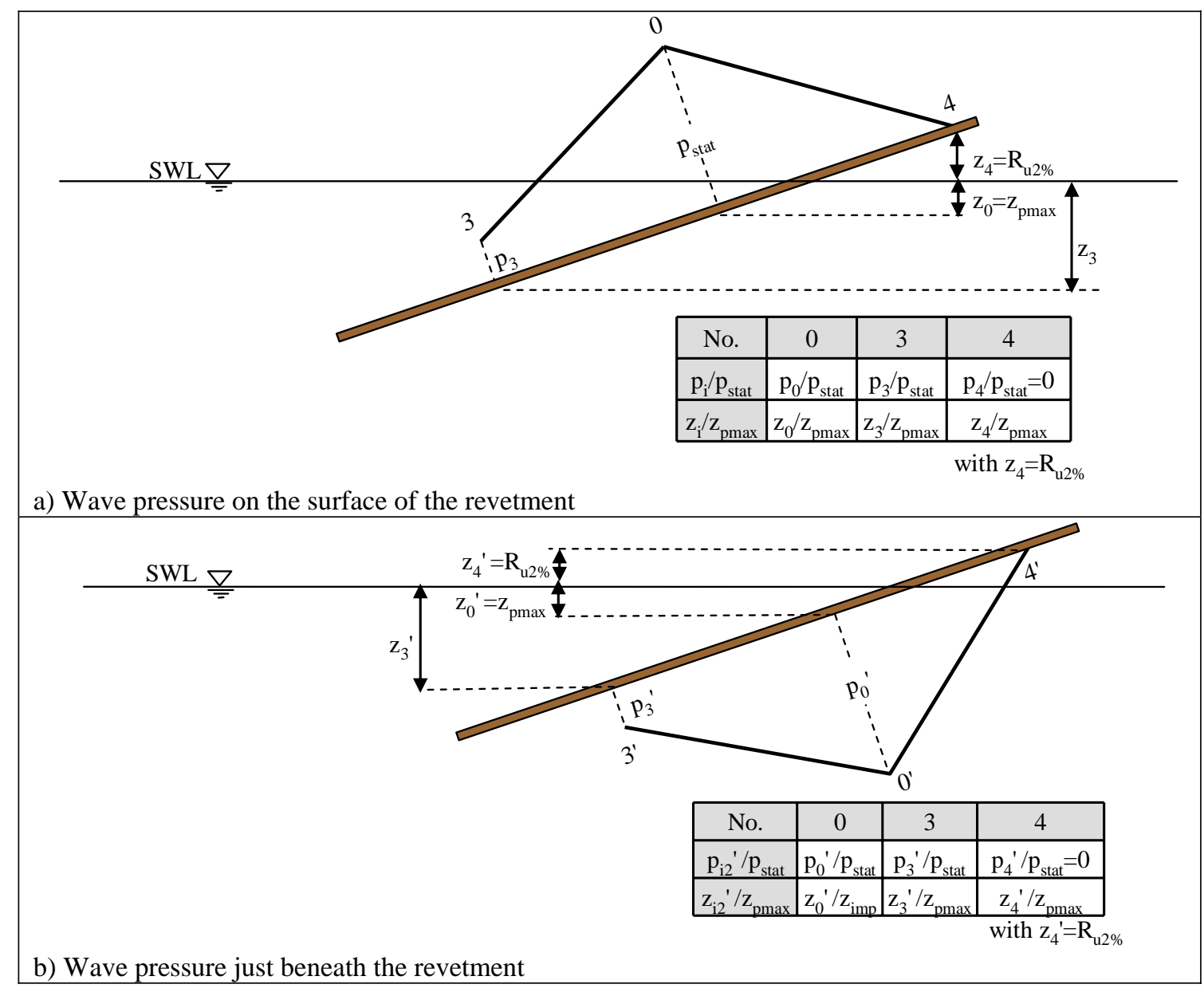

Figure 12. Parameterization of wave pressure distribution on and beneath the revetment for non-impact load.

Prediction of peak pressure $p_{\max }$ for impact load: for the pressure on the revetment the following formula is derived $\left(\sigma^{\prime}=38 \%\right)$ which is valid for $\xi_{\mathrm{m}-1,0}=1.6-2.5$ :

$\frac{\mathrm{p}_{\max }}{\rho \cdot \mathrm{g} \cdot \mathrm{H}_{\mathrm{m} 0}}=-4 \cdot \xi_{\mathrm{m}-1,0}+12.5$

Figure 13 shows that $\mathrm{p}_{\max } / \mathrm{ggH}_{\mathrm{m} 0}$-values up to 6 can be obtained. For the transition zone $\mathrm{p}_{\max } / \rho \mathrm{gH}_{\mathrm{m} 0}$-values in the order of 2 are obtained according to Fig. 13. Just beneath the revetment the $\mathrm{p}_{\max } / \mathrm{\rho gH}_{\mathrm{m} 0}$-values are reduced by a factor of about 0.6 (figure 13). 


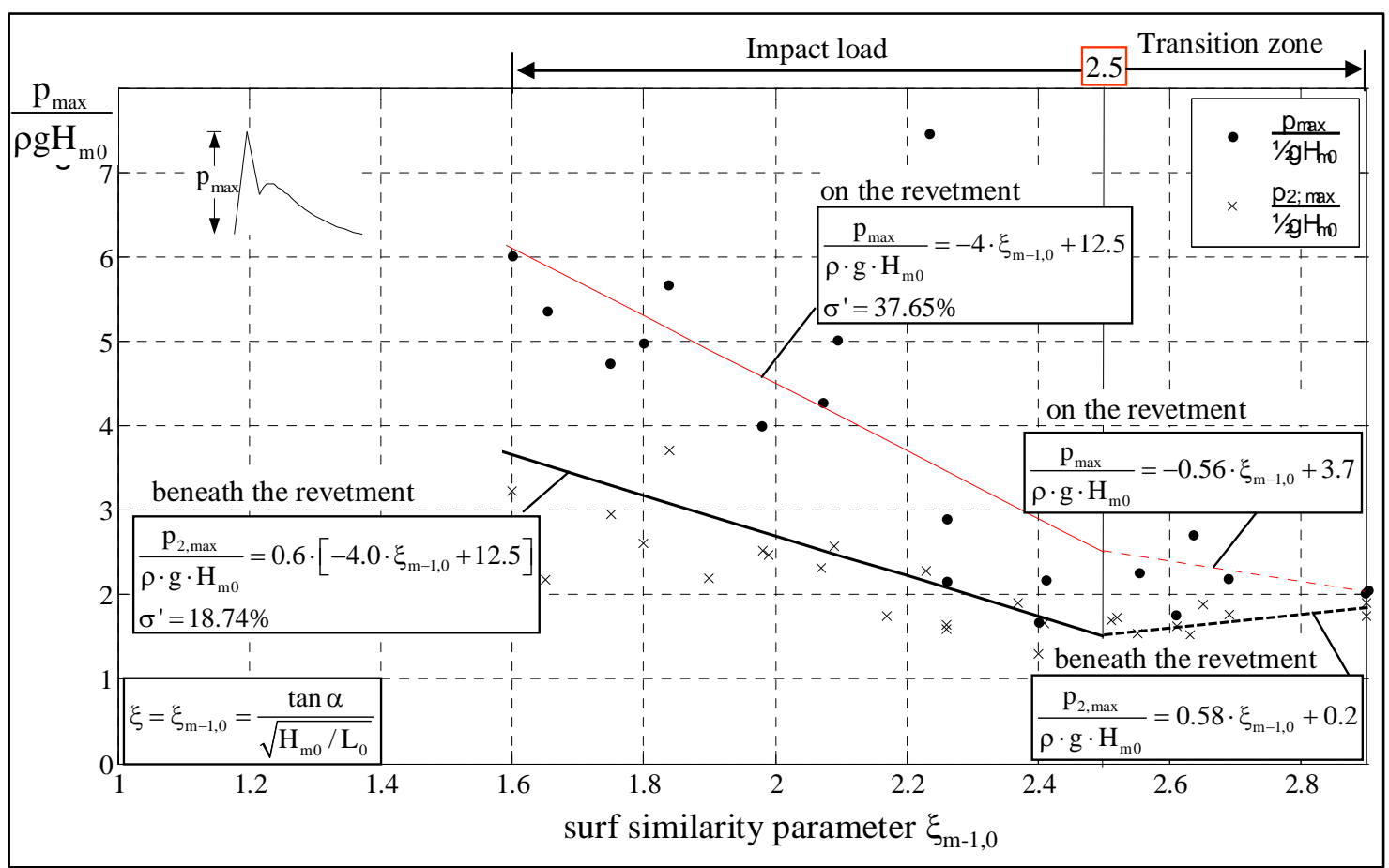

Figure 13. Peak pressure on and beneath the revetment for impact load.

Prediction of peak pressure $p_{\text {stat }}$ for non-impact load: two formulae are obtained depending on the range of the surf similarity parameter $\xi_{\mathrm{m}-1,0}$ which also covers the quasi-static component of the impact load (see figure 14).

For design purpose, it might be simpler to use only Equation (9) over the whole range of tested $\xi_{\mathrm{m}-1,0}-$ values, which is on the safe side (figure 14):

$\frac{\mathrm{p}_{\mathrm{stat}}}{\rho \cdot \mathrm{g} \cdot \mathrm{H}_{\mathrm{m} 0}}=0.68 \cdot \xi_{\mathrm{m}-1,0}$

Equation (9) can also be used for the peak pressure just beneath the revetment since the damping effect of the revetment is negligibly small.

All formulae proposed for the prediction of the peak pressure on and just beneath the revetment, including both impact load and non-impact load, are summarized in Table 1. It is important to stress that the pressure on and just beneath the revetment occurs almost simultaneously and that this should be accounted for in the stability analysis of the revetment accordingly. 


\section{XI $I^{\text {èmes }}$ Journées Nationales Génie Côtier - Génie Civil}

Les Sables d'Olonne, 22-25 juin 2010

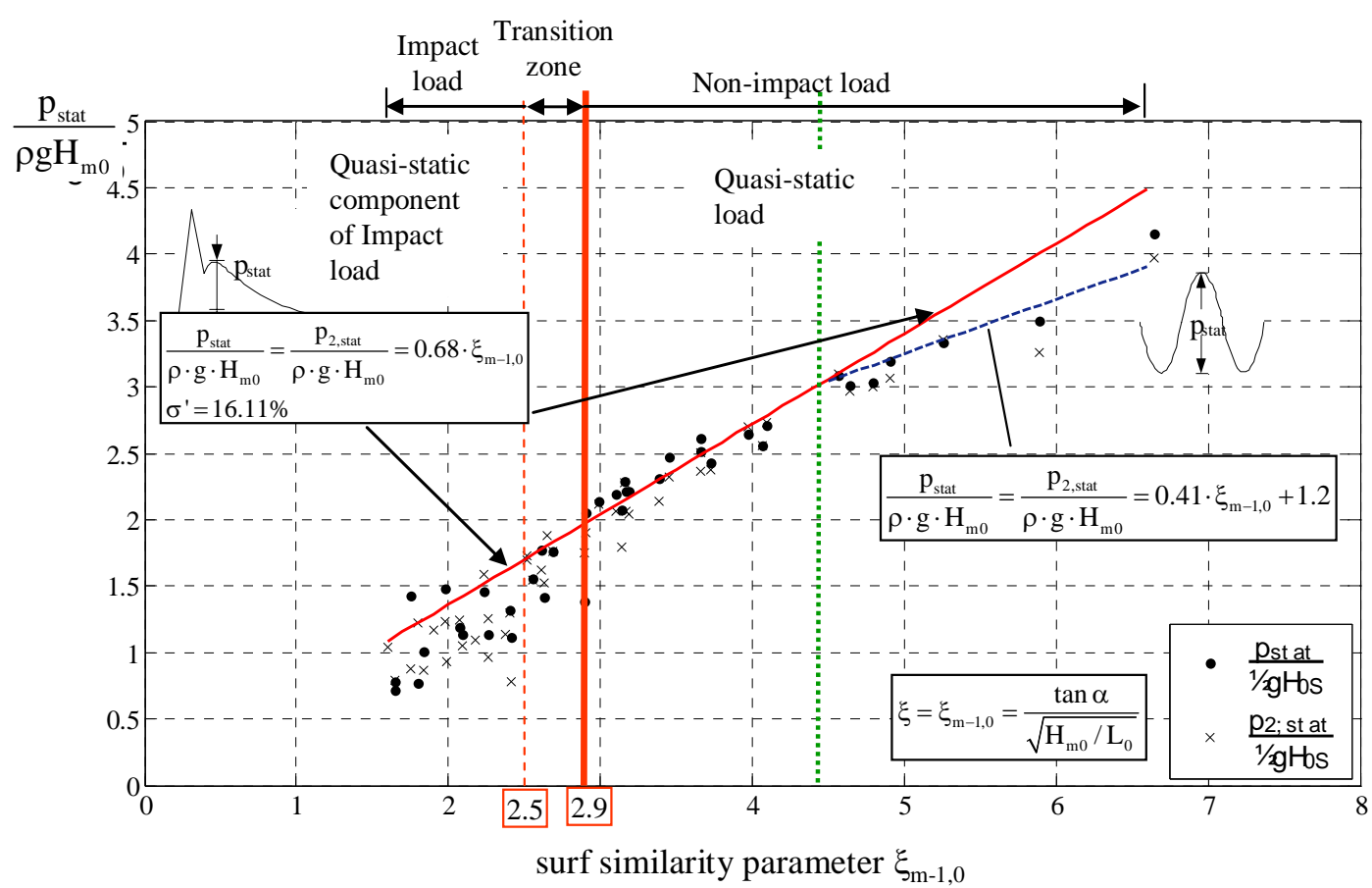

Figure 14. Peak pressure on and beneath the revetment for non-impact load.

Prediction of location of peak pressure for both impact and non impact load: two approaches leading to different prediction formulae are proposed by OUMERACI et al. (2009c). For design purpose the formulae in Equation (10) based on KLEIN BRETELER's (2007) approach with $\sigma^{\prime}=15.57 \%$ (see figure 15):

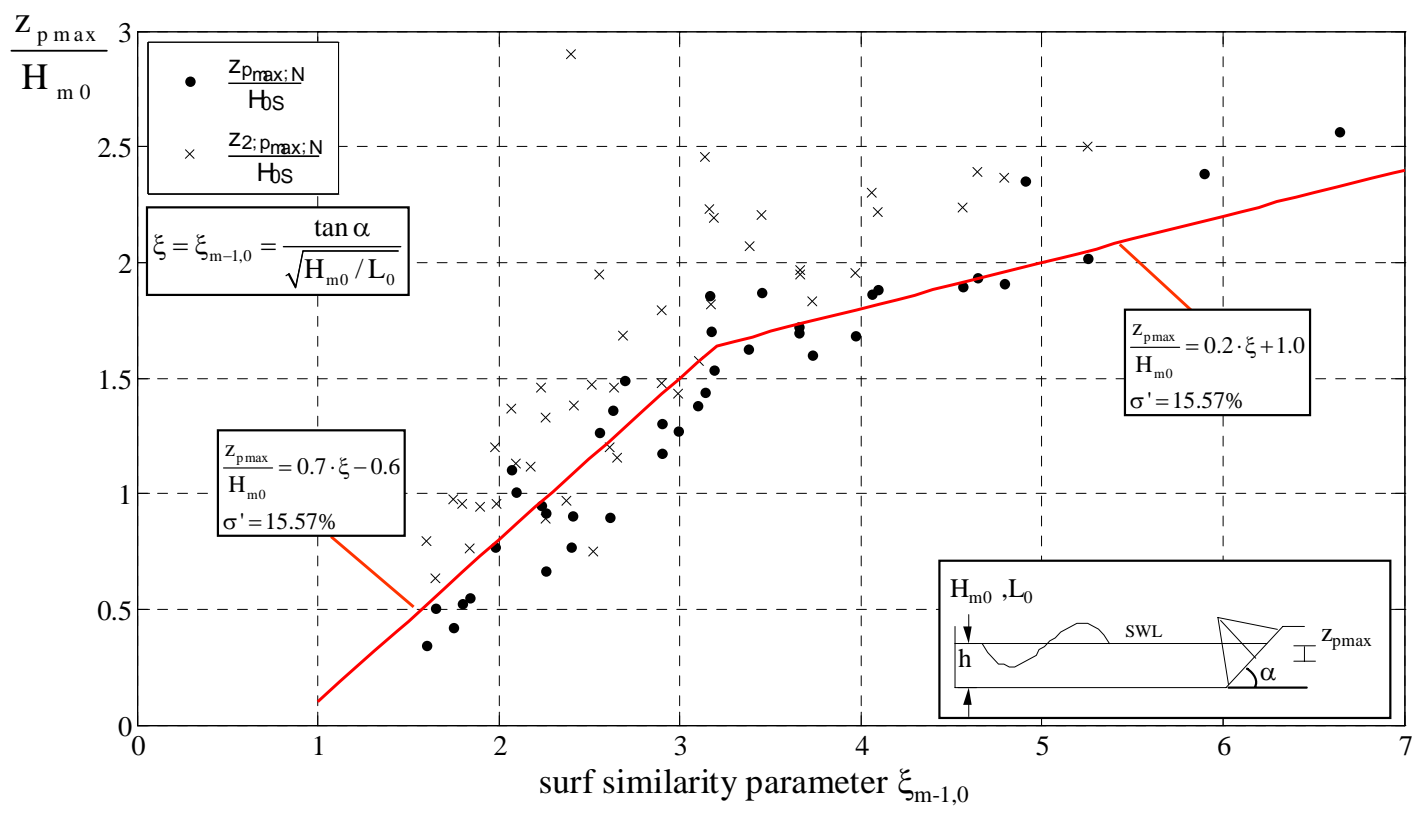

Figure 15. Location $z_{\text {pmax }}$ of peak pressure for both impact and non-impact load. 


$$
\begin{aligned}
& \frac{\mathrm{Z}_{\mathrm{pmax}}}{\mathrm{H}_{\mathrm{m} 0}}=0.7 \cdot \xi-0.6 \text { for } \xi_{\mathrm{m}-1,0}<3.2 \\
& \text { and } \\
& \frac{\mathrm{Z}_{\mathrm{p} \max }}{\mathrm{H}_{\mathrm{m} 0}}=0.2 \cdot \xi+1.0 \text { for } \xi_{\mathrm{m}-1,0}>3.2
\end{aligned}
$$

should be favoured since it is more practical and more conservative than the formula based on SCHÜTTRUMPF's (2001) approach (OUMERACI et al., 2009c). For the location of the maximum pressure induced just beneath the revetment, the same formulae as for the maximum pressure on the revetment are used by applying an amplification factor of 1.2

Spatial pressure distribution on and just beneath the revetment. It is based on the parameterization in space proposed for impact load in figure 10 and for non-impact load in figure 12. The proposed formulae to calculate all the required parameters for both impact and non-impact load are summarized in Table 1, thus allowing to determine the pressure distribution on and just beneath the revetment. It is important to stress that the pressures on and just beneath the revetment occur almost simultaneously and should be accounted for in the design accordingly. While the pressure distribution for impact load is considerably damped when transmitted just beneath the revetment, this is not the case for non-impact load for which the damping is negligibly small for practical purpose.

Time related parameters : based on the parameterization proposed for impact load in figure 9 and for non-impact load in figure 11, formulae are tentatively proposed which are summarized in Table 2. Due to the highly stochastic nature of the wave-induced pressure variations in time, the uncertainties associated with these formulae are very high, making the latter very tentative. An improvement can be achieved only through numerical modelling (planned). 


\section{XI ìmes Journées Nationales Génie Côtier-Génie Civil}

Les Sables d'Olonne, 22-25 juin 2010

Table 1. Spatial pressure distribution on and beneath revetment.

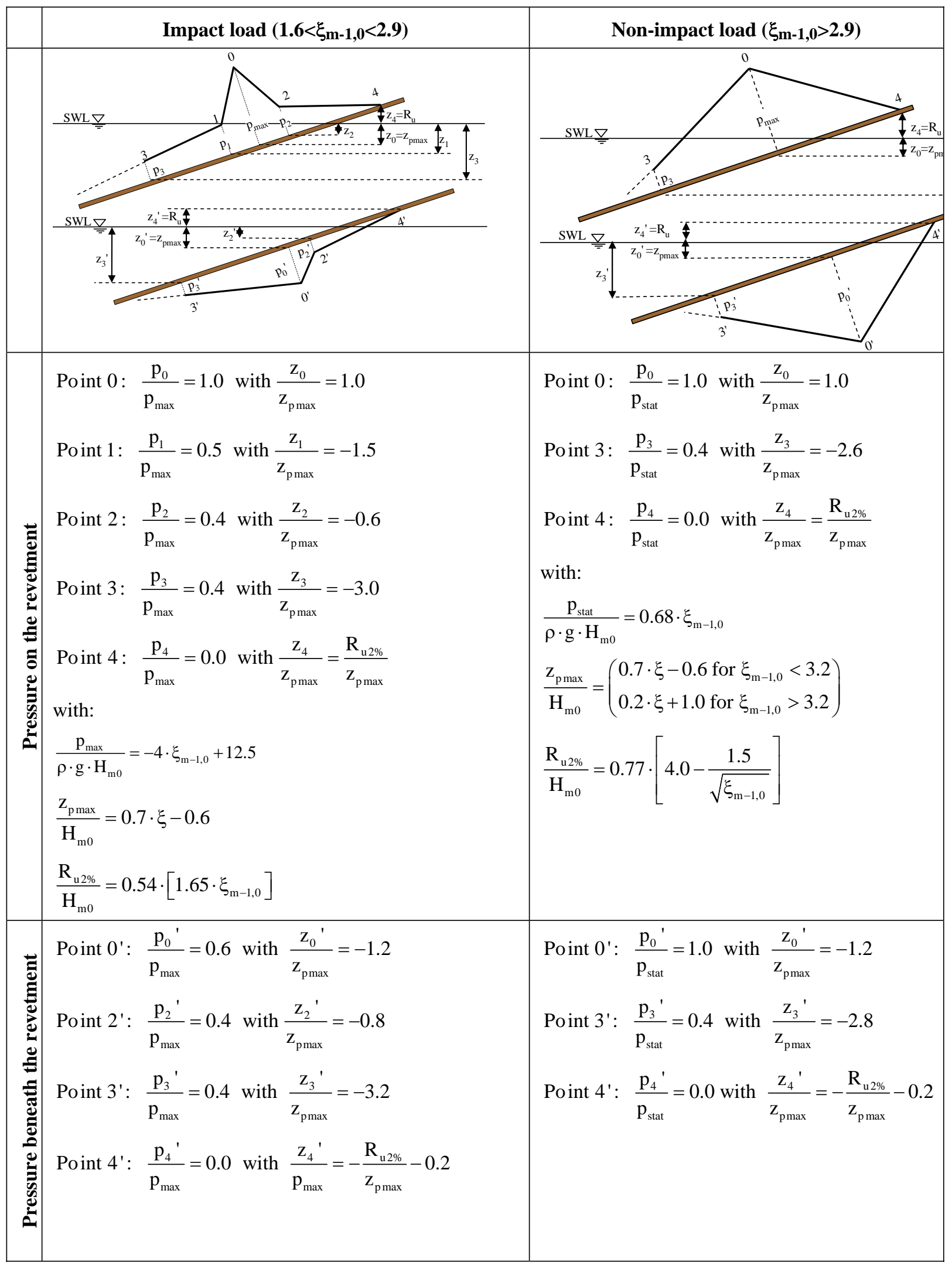


Table 2. Time related pressure parameters.

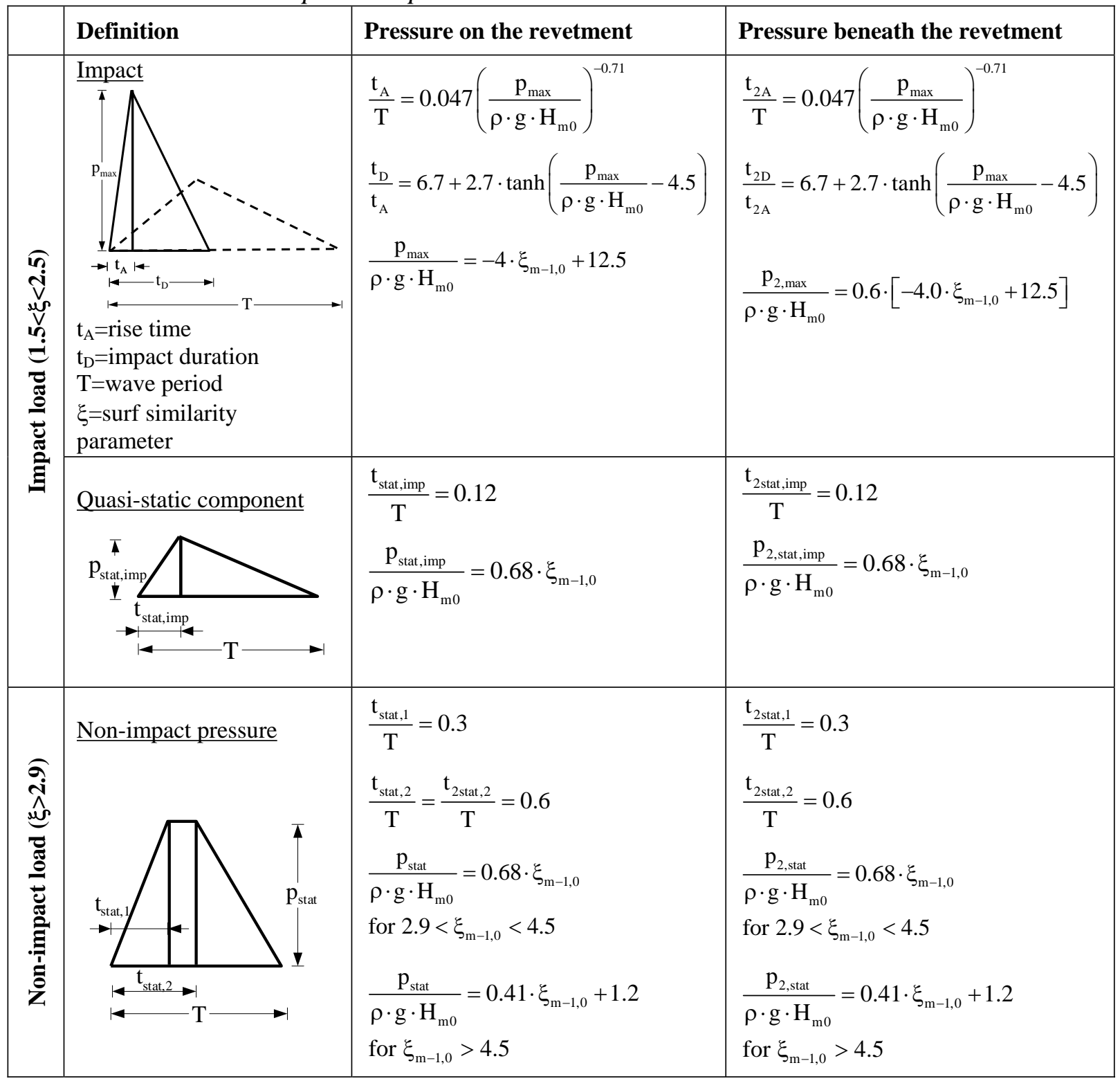

\section{Wave Induced Pore Pressure in the Sand Core beneath the Revetment}

In addition to the wave pressure on and just beneath the revetment measured at PT layers 1 and 2, respectively, pore pressure induced in the sand core beneath the revetment were also measured at PT layers 3, 4 and 5 and different locations B, C and D, as exemplarily shown for revetment Model Alternative A in figure 16 . 


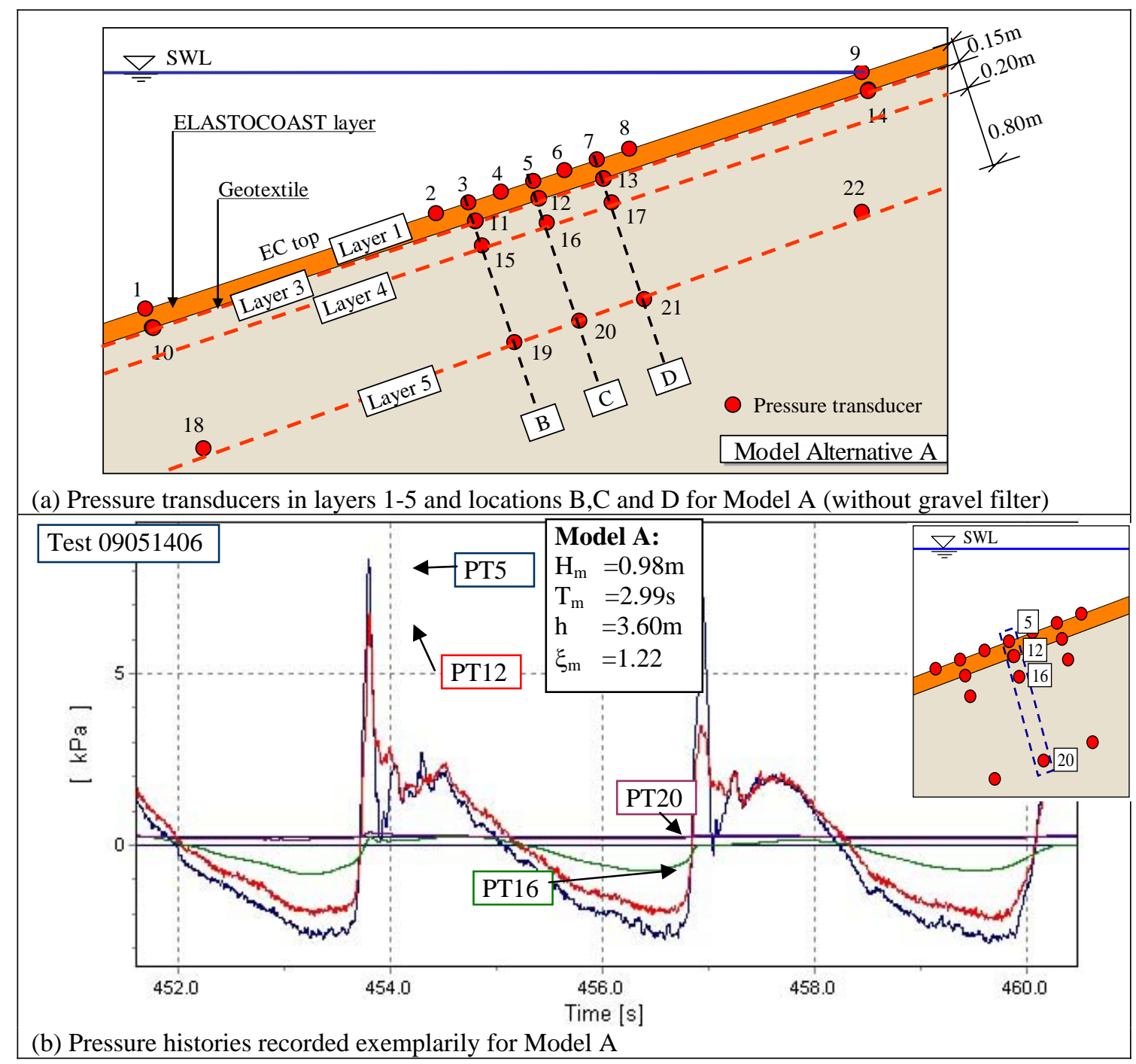

Figure 16. Pore pressure induced beneath the revetment (exemplarily for Model A).

The analysis of the wave-induced pore pressure in the sand core beneath the revetment represents an important part of the study, including both transient and residual pore pressure. Since the former were found more critical for the stability of the sand core beneath the revetment, only the results for transient pore pressure are addressed below. For more detailed and further results refer to OUMERACI et al. (2009c).

For the prediction of the transient pore pressure, focus was first put on the development of formulae to calculate the initial pressure $\mathrm{p}_{3 \max }$ at the upper boundary of the sand core beneath the revetment (PT Layer 3 in Fig. 16a). This is important because $\mathrm{p}_{3 \max }$ represents the reference pore pressure to which the damped pore pressures occurring at deeper layers are related. Surprisingly, no impact pressure component is transmitted as such into the sand core, so that all pore pressure recorded in the sand core have rather quasi-static characteristics, irrespective of the type of wave load taking place on the revetment. This made the derivation of prediction formulae for the maximum pore 
pressure at layer $3\left(\mathrm{p}_{3 \max }\right)$ and deeper layers $4-5\left(\mathrm{p}_{4 \max }\right.$ and $\left.\mathrm{p}_{5 \max }\right)$ much easier. In fact, these could be directly derived by introducing for each layer a corresponding damping factor in Eq. (9) for maximum pressure $\mathrm{p}_{\text {stat }}$ on the revetment.

The distribution of the pore pressure in deeper layers is based on the initial pressure $\mathrm{p}_{3 \max }$ at the upper boundary of the sand core beneath the revetment (Layer 3) which is used as a reference value $\mathrm{p}_{0}\left(=\mathrm{p}_{3 \max }\right)$. This distribution was analysed at three planes $\mathrm{B}$, $\mathrm{C}$ and $\mathrm{D}$ normal to the slope, showing that the damping effect is similar for all planes $\mathrm{B}$, $\mathrm{C}$, and $\mathrm{D}$, and that the damping rate significantly depends on initial pressure $\mathrm{p}_{0}$ (see figures 16 and 17 and OUMERACI et al. 2009c).

The obtained prediction formulae for the maximum pore pressure at PT layers 3, 4 and 5 in the sand core are summarized in figure 17, also including Equation (9) for peak pressure $\mathrm{p}_{\text {stat }}$ on the revetment. These formulae show that the pore pressure is almost completely damped at a depth of about $80 \mathrm{~cm}$ in the sand core beneath the revetment.

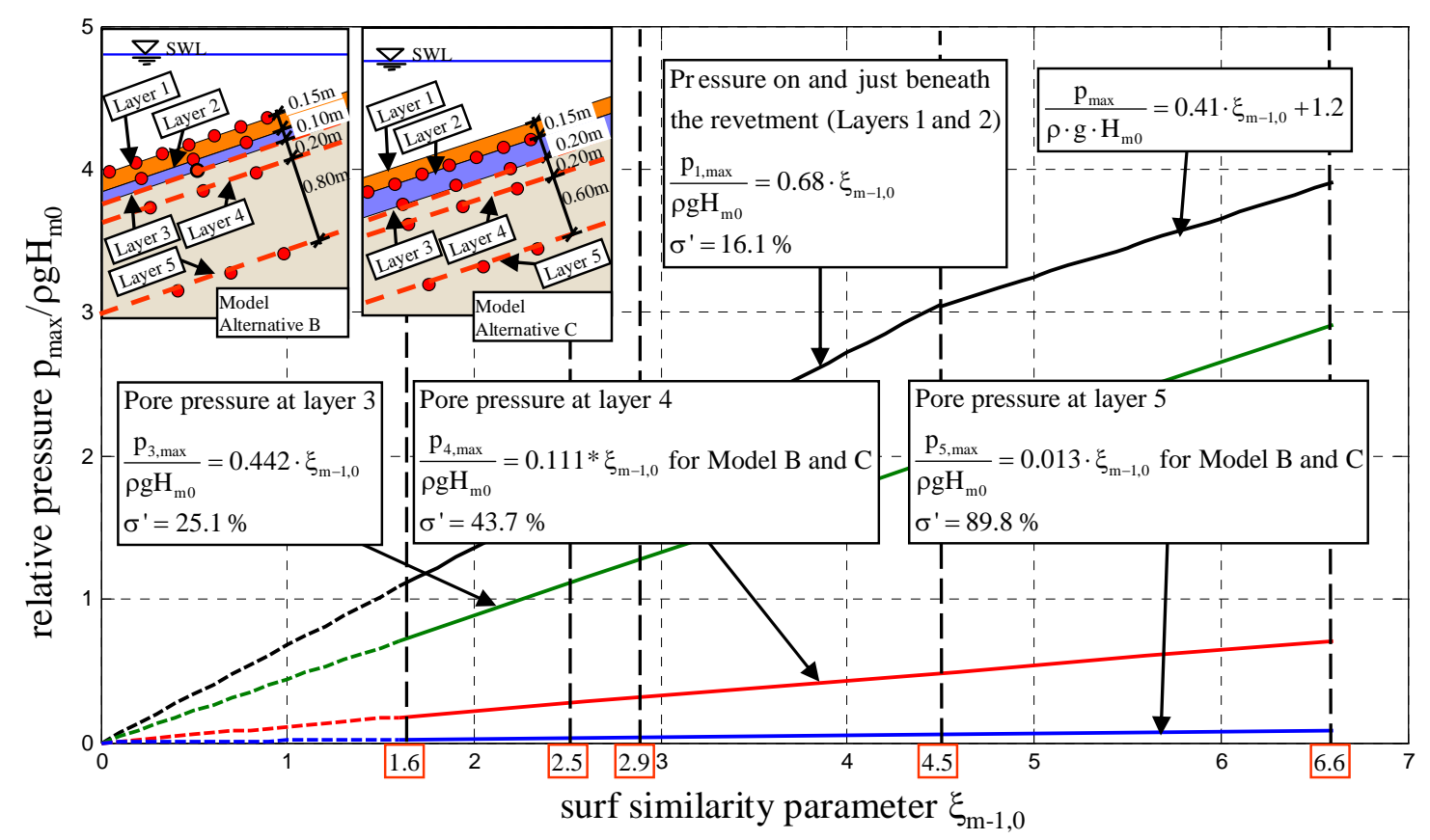

Figure 17. Proposed formulae for the damping of wave induced peak pressure at different layers beneath the revetment as a function of surf similarity parameter $\xi_{m-1,0}$.

\section{Flexural Displacements}

For the prediction of the flexural displacements (bending) of the ELASTOCOAST revetment, formulae are proposed which relate the displacement $\delta$ (in $\mathrm{mm}$ ) and the maximum pressure $\mathrm{p}_{\text {stat }}$ (in $\mathrm{kPa}$ ) on the revetment of the non-impact load (figure 18). 


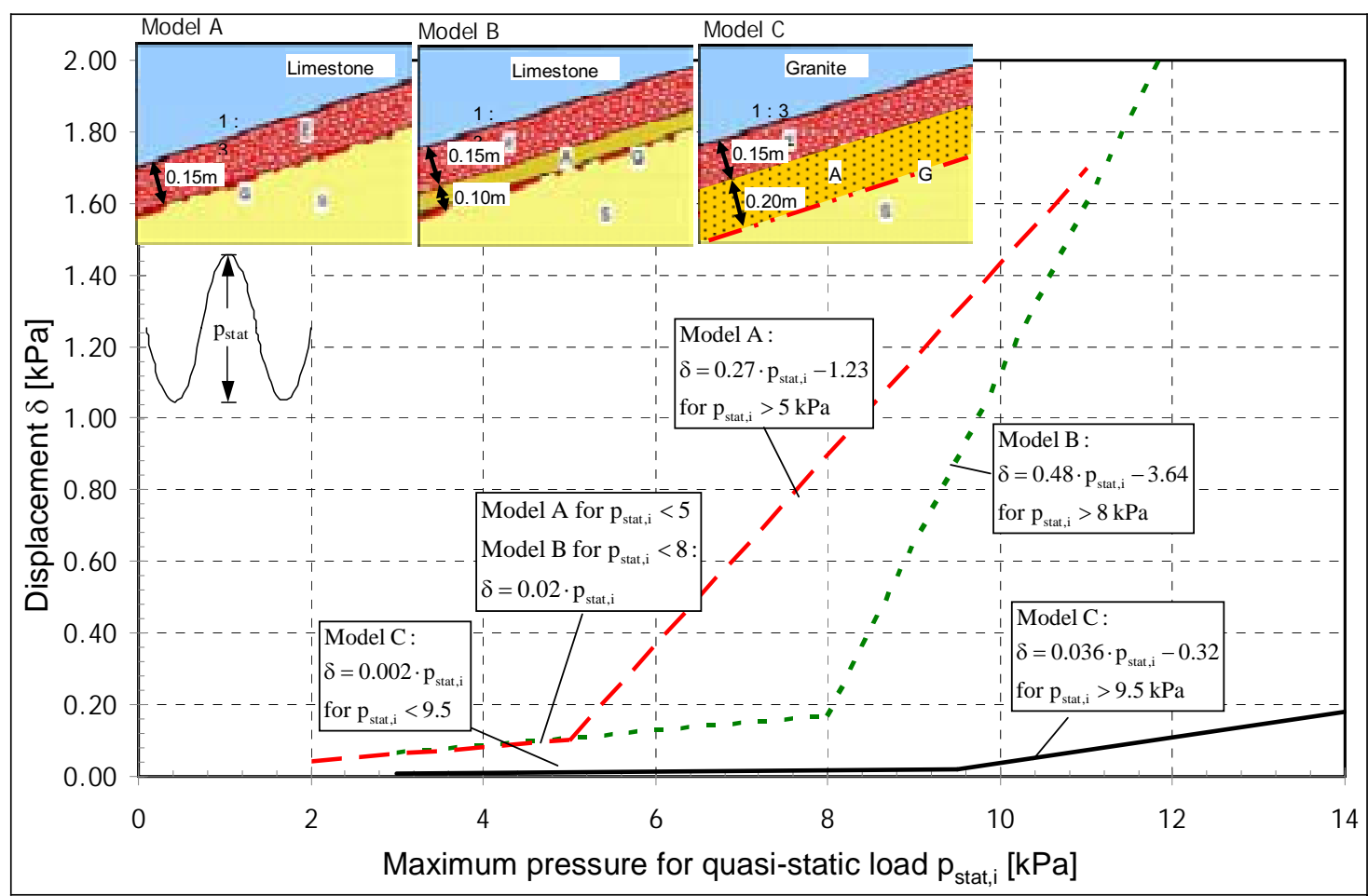

Figure 18. Proposed prediction formulae for flexural displacement $\delta$ (in $\mathrm{mm}$ ) of the revetment as a function of peak pressure $p_{\text {stat }}$ (in $\mathrm{kPa}$ ).

In fact, the impact load induces comparatively smaller displacements and the relationship between displacement $\delta$ and peak pressure $\mathrm{p}_{\max }$ exhibits a considerable scatter, so that a derivation of formulae for impact load is not necessary (OUMERACI et al., 2009c).

As expected, the smallest displacement occurs for Model Alternative $\mathrm{C}$ with the thickest -and thus the stiffest-gravel layer. A further detailed analysis using a numerical model will be performed at a later stage.

\section{Failure of revetment model $A$}

The failure of revetment model A (figure 2a) occurred under regular wave attack with $\mathrm{H}=1.3 \mathrm{~m}$ and $\mathrm{T}=5 \mathrm{~s}$ for a water depth of $\mathrm{h}=3.90 \mathrm{~m}$, while for the simultaneously tested Model B (figure $2 \mathrm{~b}$ ) under exactly the same wave conditions no failure occurred. In a previous test with the same water depth $(\mathrm{h}=3.90 \mathrm{~m})$, the same wave height $(\mathrm{H}=1.3 \mathrm{~m})$, but with a shorter wave period $(\mathrm{T}=4 \mathrm{~s})$, no apparent damage occurred for Models A and B. Therefore, this section aims at briefly describing the observed damage of Model A and at providing a possible physical interpretation of the experienced failure which is based on video observations and on the analysis of the recorded data related to the wave-induced pressure and the associated displacement of the revetment. 
Description of observed failure of Model A: The exact time at which the collapse of Model A occurred is identified by means of the records of the displacement meter as illustrated by figure 19, showing comparatively the recorded displacement for Model A and Model B. It is seen that the collapse of Model A started after $t=450 \mathrm{~s}(\mathrm{t}=7: 30 \mathrm{~min})$, i.e. between the $74^{\text {th }}$ and the $75^{\text {th }}$ wave of Test 09051802 .

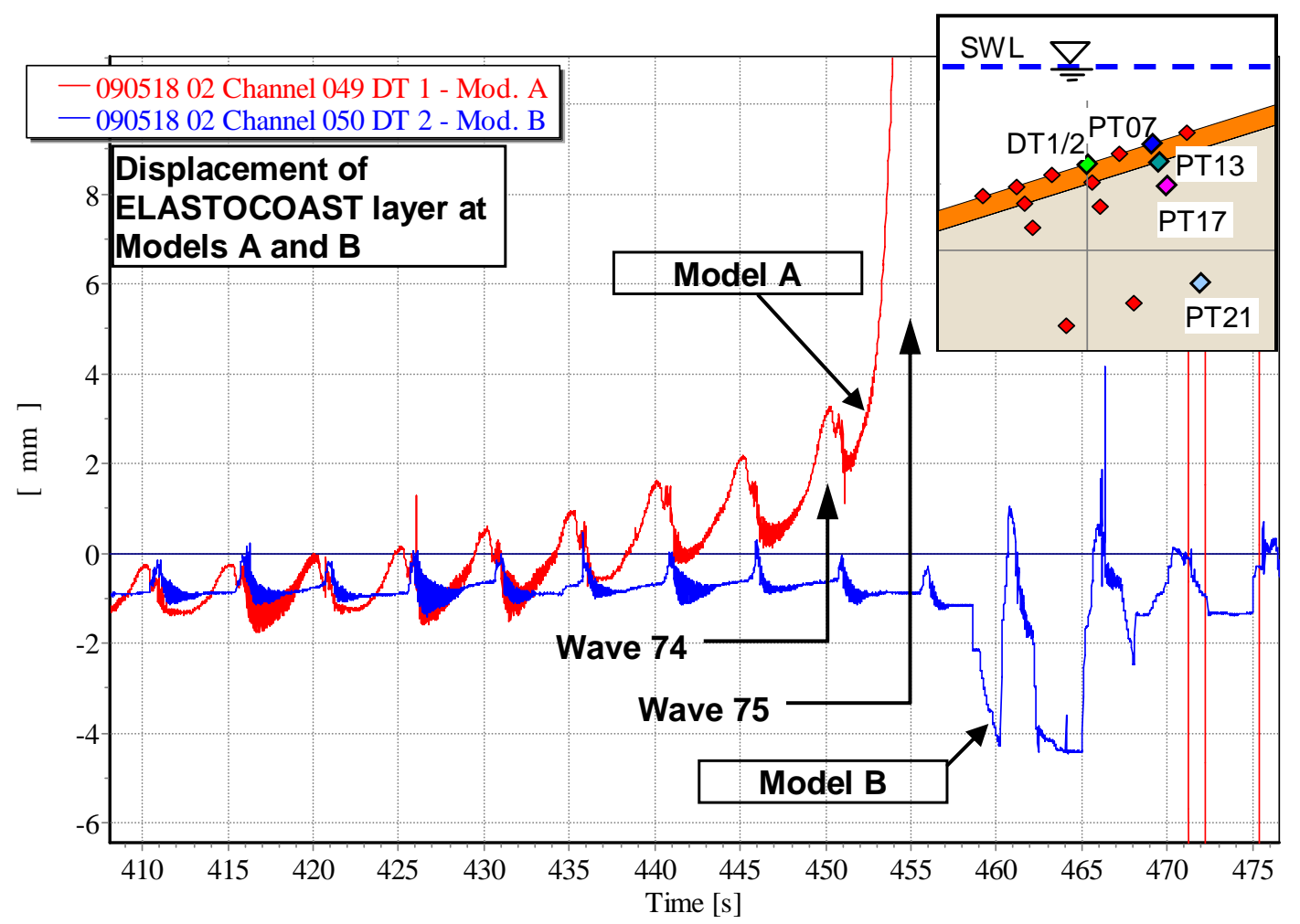

Figure 19. Displacement signals for Models A and B at the time of failure of Model A.

In fact, the failure initiation started just after $\mathrm{t}=430 \mathrm{~s}(\mathrm{t}=7: 10 \mathrm{~min})$, i.e. just after the 70th wave, where a residual upward displacement started to build up for each cycle until the collapse occurred. The uplift of the revetment by each wave cycle causes a gap beneath the revetment, thus allowing the sediment to move more freely. As a result, the residual upward displacement increases progressively until the collapse occurs. The maximum residual upward displacement $(15 \mathrm{~mm})$ was recorded by the displacement meter during the run down of the 75th wave which caused the collapse of the revetment. As observed visually during the tests, the collapse occurred within a very short time interval (few seconds) without any visually perceptible precursors. Following the significant upward motion of the revetment and the resulting gaps beneath the revetment, a considerable amount of sand was washed out by the receding waves on the slope (down rush flow). As a result, a significant settlement of the revetment and a subsequent breakage of the revetment occurred. As shown in figure $21 \mathrm{a}$, the washed sand was deposited at the toe 


\section{XI ìmes Journées Nationales Génie Côtier-Génie Civil}

Les Sables d'Olonne, 22-25 juin 2010

of the revetment. This figure together with figure $21 \mathrm{~b}$ shows that the occurrence of the collapse was spatially concentrated just below still water level.

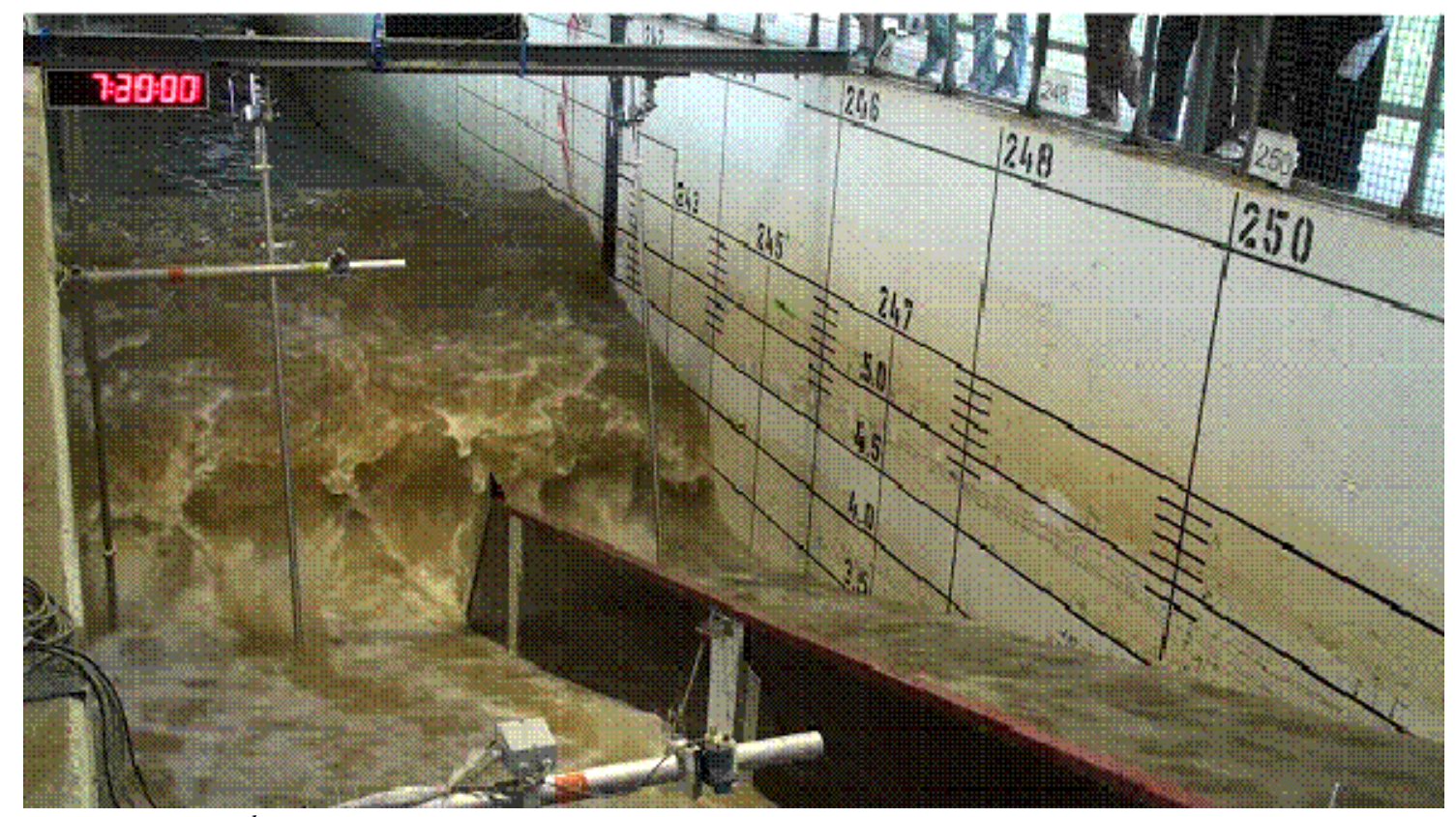

Figure $20.74^{\text {th }}$ wave at $t=450$ s (7:30min) just before impact on the revetment in GWK.

Comparatively, no build up of the residual displacement (figure 22) and no damage (figure 19) occurred for Model B which was subject to the same incident waves as Model A.

Following the wash out of sand and the subsequent settlement, the revetment experienced an unexpected breakage in several smaller and larger block units, leading to very large gaps through the revetment. This unexpected breakage behaviour is certainly due to the use of limestones, since the observed failure planes are generally through the limestones and not through the polyurethane binding material.

Physical interpretation of the failure: The primary difference between Model A which failed and Model B which did not fail under the same wave conditions is the $10 \mathrm{~cm}$ thick gravel filter layer (compare figures $2 \mathrm{a}$ and $2 \mathrm{~b}$ ) which provides an additional weight and stiffness for Model B to resist against soil failure (e.g. reduction of shear resistance and soil liquefaction) of the sand core beneath the revetment which is subject to different pore pressures in both Models A and B. 


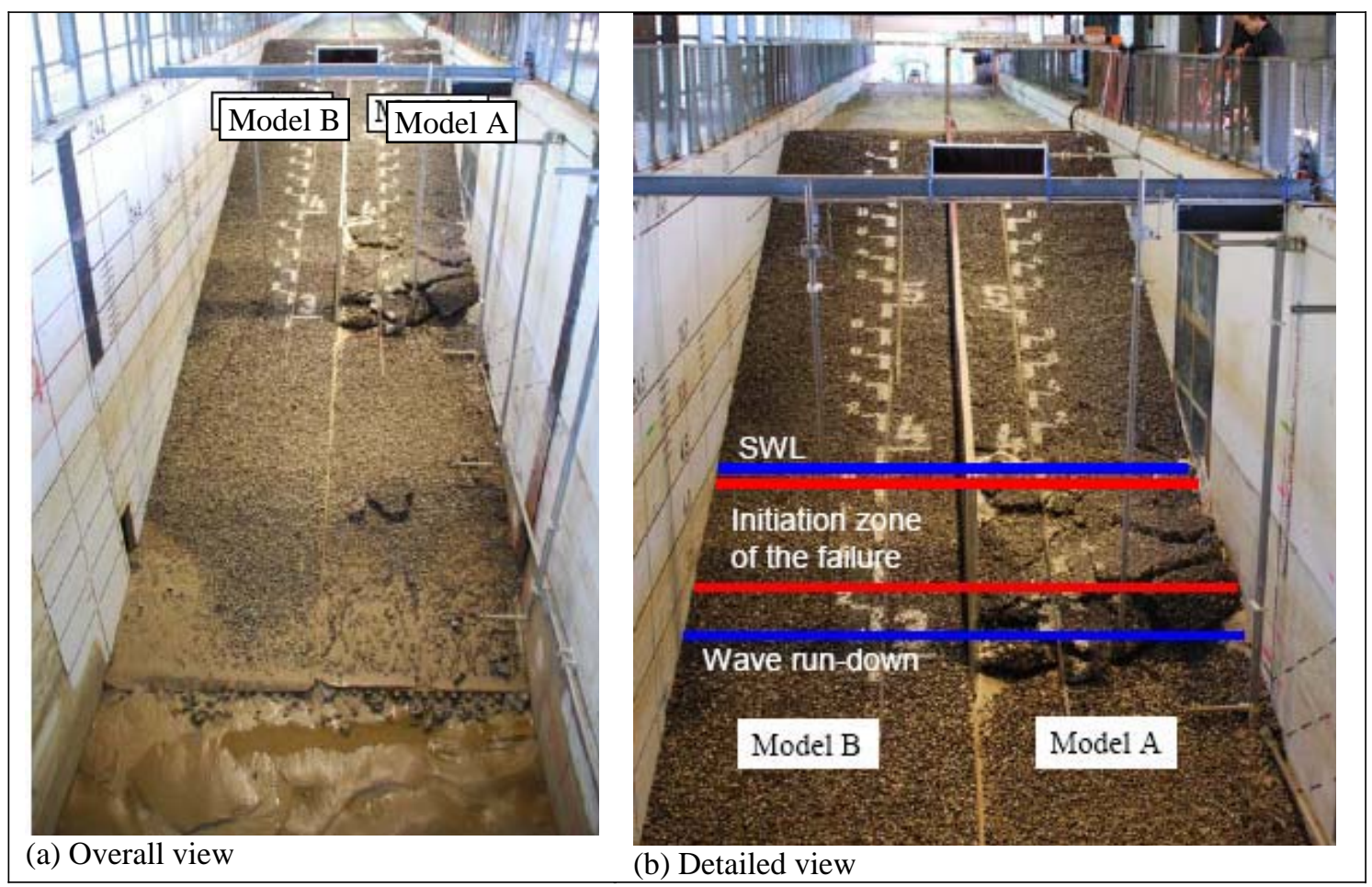

Figure 21. Extent of damage for revetment Model A after regular wave test 09051802.

The wave pressure on and beneath the revetment are almost similar for both Models A and B with the uplift pressure being slightly higher for Model A than for Model B (OUMERACI et al., 2009a; OUMERACI et al., 2009b; OUMERACI et al., 2009c). However, the response of the sand core beneath the revetment is different for Model A and Model B as shown by the development of the pore pressure in figure 22 before failure. It is seen that the "negative" pore pressure amplitudes measured in $20 \mathrm{~cm}$ beneath the upper boundary of the sand core by pressure transducer PT17 on Model A and by PT43 in Model B significantly differ, while the "positive" pore pressure amplitudes are in the same range for both models A and B. In fact, the "negative" pore pressure amplitudes are almost twice for Model A (-2.3 kPa) than for Model B $(-1.2 \mathrm{kPa})$. This extremely higher "negative" pressure gradient beneath Model A induced a significantly stronger upward water flow in the sand core beneath the revetment as compared to Model B. It should be stressed that the pore pressure signals shown in figure 22 are recorded long before the occurrence of the failure and that about 10 waves before the collapse at $\mathrm{t}=455 \mathrm{~s}$ the pore pressure amplitudes remained almost constant over time.

This is surprisingly not the case for the last 10 waves before the failure occurred. As shown in figure 23, the "negative" pore pressure amplitudes at PT17 for Model A progressively increases from $-2.4 \mathrm{kPa}$ at $\mathrm{t}=410 \mathrm{~s}$ to $-3.2 \mathrm{kPa}$ at $\mathrm{t}=445 \mathrm{~s}$, i.e. just before incipience of the failure, while the "positive" pore pressure amplitudes remained almost constant over time. As the failure started $\left(74^{\text {th }}\right.$ wave at $\left.t=450 \mathrm{~s}\right)$, the pore pressure 


\section{XI $I^{\text {èmes }}$ Journées Nationales Génie Côtier - Génie Civil}

Les Sables d'Olonne, 22-25 juin 2010

decreased to $-5.6 \mathrm{kPa}$ and dropped to $-11.4 \mathrm{kPa}$ as the revetment collapsed $\left(75^{\text {th }}\right.$ wave at $\mathrm{t}=455 \mathrm{~s}$ ). As shown by the simultaneously measured displacement of the revetment, the progressive increase in "negative" pore pressure amplitude is accompanied by a simultaneously progressive increase of the upward displacement of the revetment up to the time where the displacement meter collapsed.

These results indicate that the failure of Model A is most probably caused by the transient liquefaction of the sand core beneath the revetment. To confirm this result, a comparative stability analysis of Models A and B for the same tests at which the failure of Model A occurred is provided below.

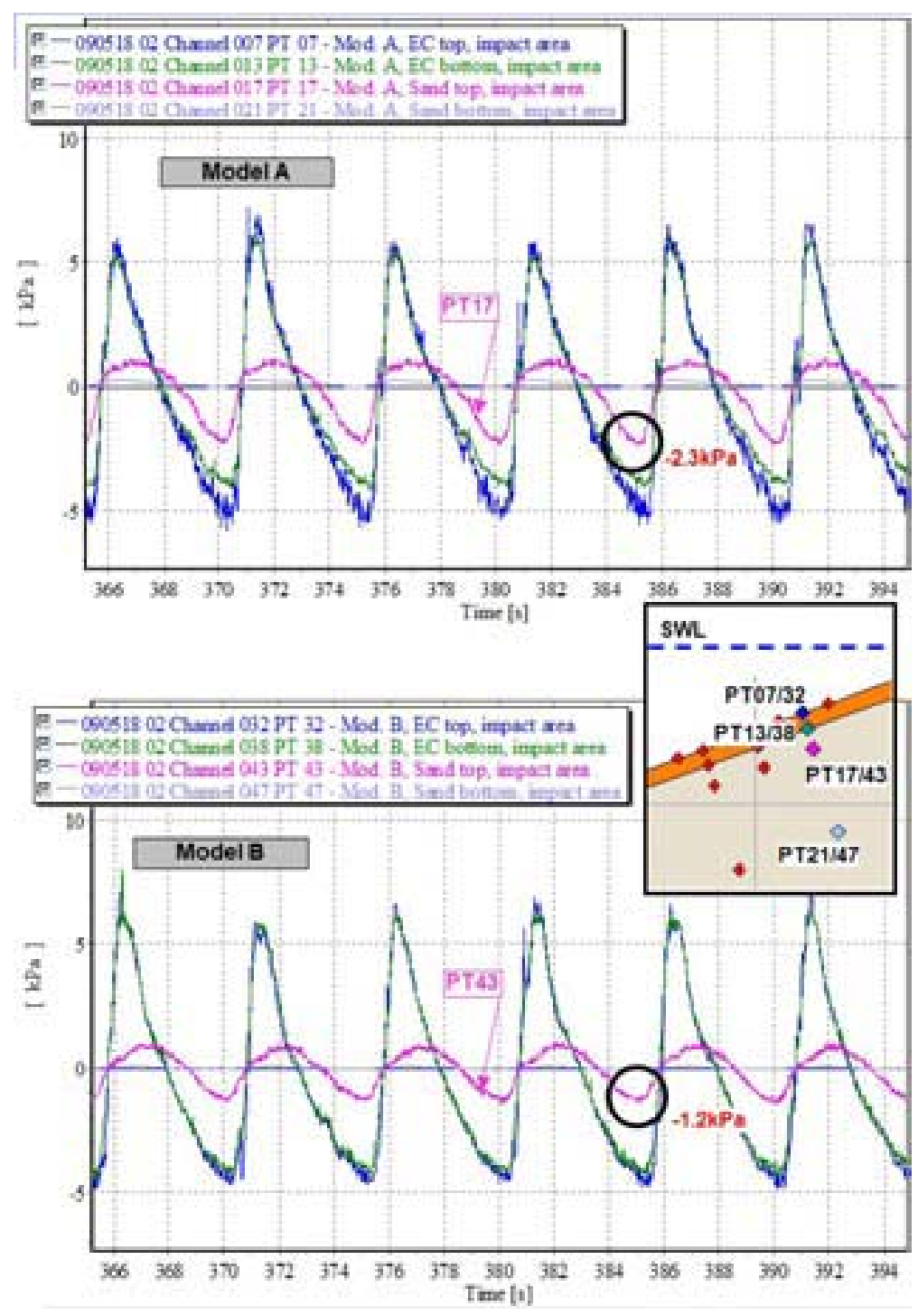

Figure 22. Pore pressure development in the sand underneath the revetment (OUMERACI et al., 2009a; OUMERACI et al., 2009b; OUMERACI et al., 2009c). 


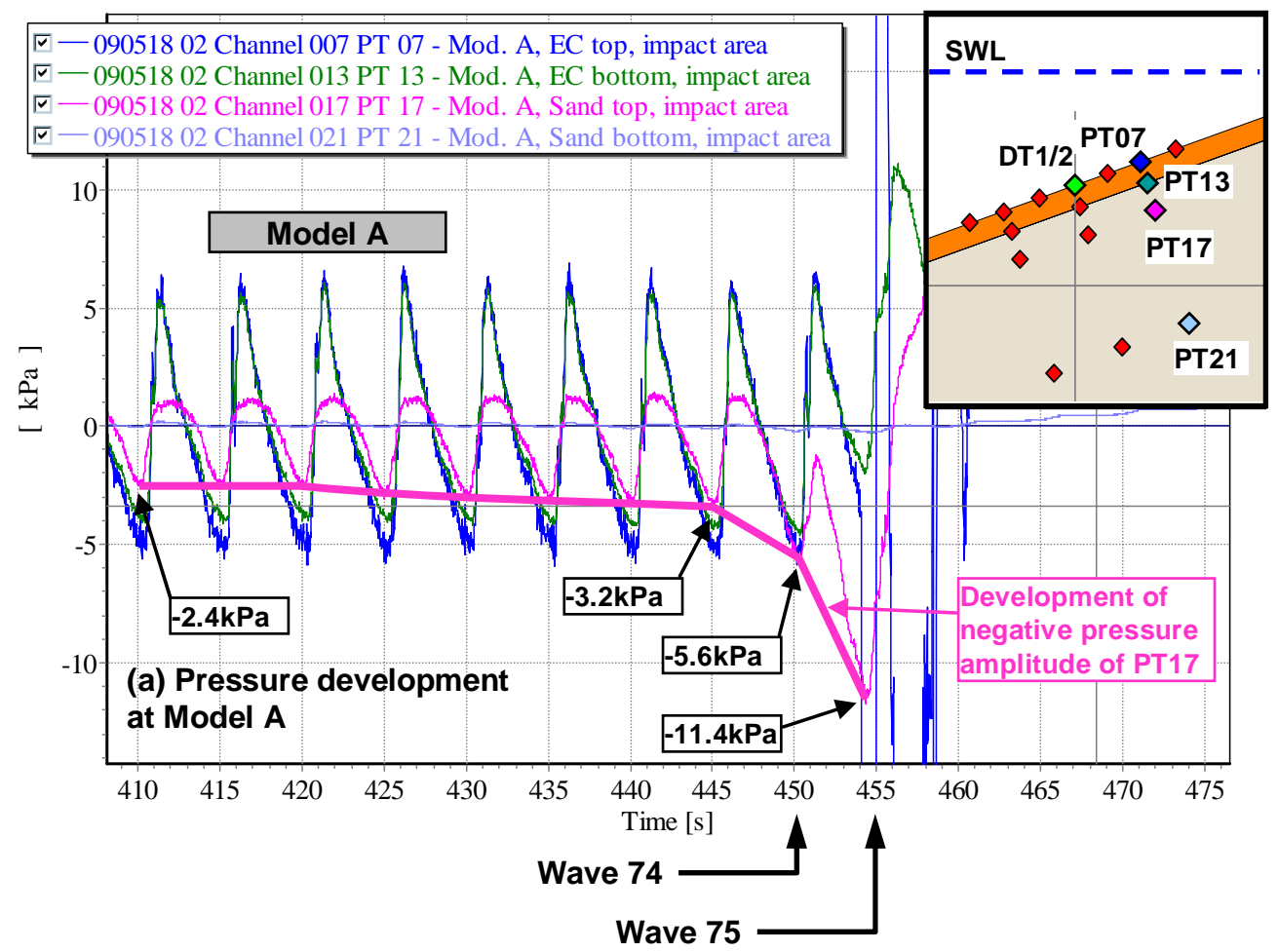

Figure 23. Pore pressure development in the sand core beneath the revetment of Model A just before collapse.

\section{Stability analysis of sand core beneath the revetment against soil liquefaction:}

Generally, wave-induced cyclic loads generate both pore water pressure $u$ and effective stresses $\sigma^{\prime}$ inside the subsoil. The total pore pressure $\mathrm{u}_{\mathrm{tot}}(\mathrm{z}, \mathrm{t})$ in the seabed is composed of the hydrostatic component $\mathrm{u}_{0}(\mathrm{z})$ and the wave induced component $\mathrm{u}(\mathrm{z}, \mathrm{t})$ :

$\mathrm{u}_{\mathrm{tot}}(\mathrm{z}, \mathrm{t})=\mathrm{u}_{0}(\mathrm{z})+\mathrm{u}(\mathrm{z}, \mathrm{t})$

The wave-induced component $\mathrm{u}(\mathrm{z}, \mathrm{t})$ is also called "excess pore pressure" (in excess of the hydrostatic pressure). Because of the resetting of the pressure transducers to zero $(\mathrm{u}=0)$ at still water level before each individual test, the initial hydrostatic component $\mathrm{u}_{0}(\mathrm{z})$ is not considered in the data analysis.

Liquefaction occurs, if the excess pore pressure $\mathrm{u}(\mathrm{z}, \mathrm{t})$ inside the soil reaches the value of the initial effective stress $\sigma_{0}^{\prime}$ which means, that the shear resistance $\tau_{\mathrm{s}}$ of the soil tends to zero $\left(\tau_{\mathrm{s}}=\left(\sigma^{\prime}-\mathrm{u}\right) \tan \varphi\right.$ with $\varphi=$ internal friction angle $)$. In general, soil liquefaction may be induced by two mechanisms (i) upward pressure gradient in the soil during the passage of the wave trough (transient or instantaneous liquefaction and (ii) Build up of mean excess pore water pressure (residual liquefaction)

During the passage of a wave trough the induced excess pore pressure in the soil becomes "negative" in the sense that an upward directed pressure gradient $\left(u_{o}-u_{t}\right)$ is generated. This gradient results from the decrease of transient pore pressure $u_{t}$ with increasing depth $\mathrm{z}^{\prime}$ (figure 24). 

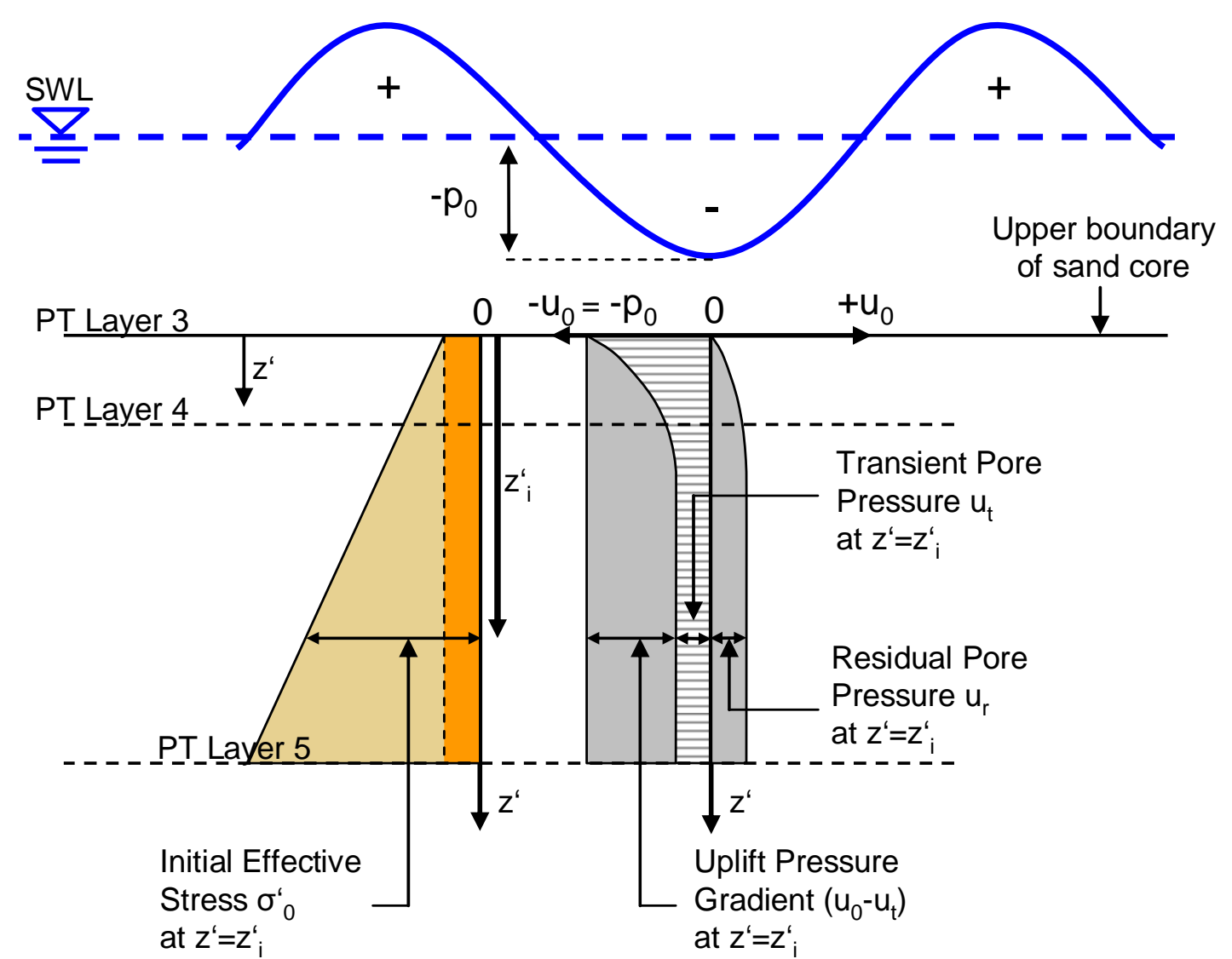

Figure 24. Distribution of initial effective stress, excess pore pressure amplitude and uplift pressure gradient in the sand core under the passage of a wave trough (see figures 16 \& 17 for definition of PT Layers 3-5).

If the pressure gradient $\left(\mathrm{u}_{\mathrm{o}}-\mathrm{u}_{\mathrm{t}}\right)$ at a certain location $\mathrm{z}$ in the sand core reaches the effective stress $\sigma^{\prime}{ }_{\text {vo }}$ due to the submerged weight of the soil $\left(\sigma_{\mathrm{v} 0}^{\prime}\right)_{\mathrm{s}}$ and that of the revetment $\left(\sigma_{\mathrm{v} 0}^{\prime}\right)_{\mathrm{r}}$ at this location,

$\sigma^{\prime}{ }_{v 0}=\underbrace{\rho_{s}^{\prime} \cdot g \cdot z}_{\left(\sigma_{v 0}\right)_{s}}+\underbrace{\rho_{\mathrm{r}} \cdot g \cdot d_{r}}_{\left(\sigma_{v v}\right)_{r}}$

with:

$\sigma_{\mathrm{v} 0}^{\prime} \quad\left[\mathrm{N} / \mathrm{m}^{2}\right] \quad$ Initial effective vertical stress

$\rho_{\mathrm{s}}^{\prime} \quad\left[\mathrm{kg} / \mathrm{m}^{3}\right] \quad$ Bulk density of submerged soil (sand)

$\rho_{\mathrm{s}} \quad\left[\mathrm{kg} / \mathrm{m}^{3}\right] \quad$ Bulk density of soil (sand)

$\rho_{\mathrm{w}} \quad\left[\mathrm{kg} / \mathrm{m}^{3}\right] \quad$ Mass density of water

g $\quad\left[\mathrm{m} / \mathrm{s}^{2}\right] \quad$ Gravitational acceleration

$\mathrm{z} \quad[\mathrm{m}] \quad$ Depth of sand core

$\rho_{\mathrm{r}} \quad[\mathrm{kg} / \mathrm{m} 3] \quad$ Density of revetment including filter layer

$\mathrm{d}_{\mathrm{r}} \quad[\mathrm{m}] \quad$ Thickness of filter layer and Elastocoast revetment 
the soil gets into suspension and behaves like a fluid. This is called transient soil liquefaction, as this phenomenon is limited to the short period during the passage of the wave trough.

Transient liquefaction occurs if the pressure difference $\left(\mathrm{u}_{0}-\mathrm{u}_{\mathrm{t}}\right)=0$ becomes equal to or or larger than the initial effective stress $\sigma^{\prime}{ }_{\mathrm{v} 0}$ :

$\sigma^{\prime}{ }^{\prime} 0-\left(u_{0}-u_{t}\right)=0$

with:

$\sigma_{\mathrm{v} 0}^{\prime} \quad \mathrm{N} / \mathrm{m}^{2} \quad$ Initial effective vertical stress

$\mathrm{u}_{0} \quad\left[\mathrm{~kg} / \mathrm{m}^{3}\right] \quad$ Initial (hydrostatic) pore water pressure

$\mathrm{u}_{\mathrm{t}} \quad \mathrm{Pa} \quad$ Instantaneous (transient) excess pore water pressure

Moreover, residual (or mean) pore pressure ur may build up gradually from cycle to cycle. If it reaches the value of the initial effective normal stress $\sigma^{\prime}{ }_{\mathrm{v} 0}$, the contact between the soil grains vanishes and the soil behaves like a fluid. This is called residual soil liquefaction:

$\sigma^{\prime}{ }_{\mathrm{v} 0}-\mathrm{u}_{\mathrm{r}}=0$

with:

$\mathrm{u}_{\mathrm{r}} \quad[\mathrm{Pa}] \quad$ Residual excess pore water pressure

Though residual pore pressure is relatively rare or not significant under wave action alone, both residual pore pressure ur and transient pore pressure ut should be considered in the limit state equation for soil liquefaction:

$\sigma^{\prime}{ }_{v 0}-\left[\left(u_{0}-u_{t}\right)+u_{r}\right]=0$

Based on Equation (15), the stability analysis of the sand core beneath the revetment against soil liquefaction can be performed as schematically illustrated in figure 25 .

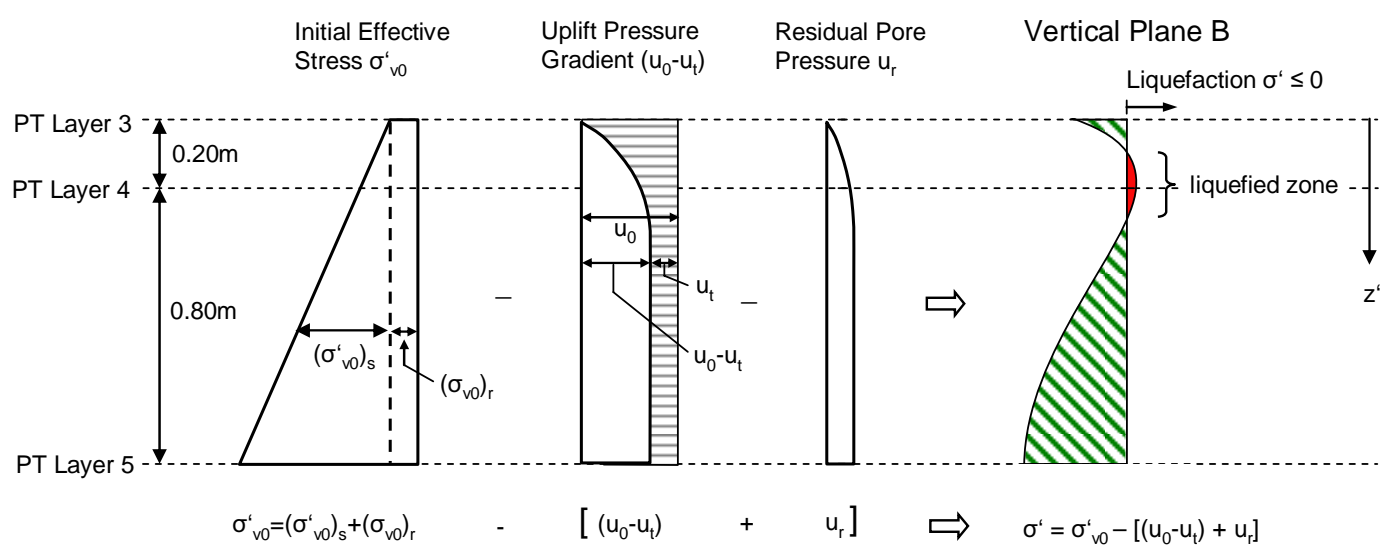

Figure 25. Stability analysis against soil liquefaction beneath the revetment (principle sketch). 


\section{XI $I^{\text {èmes }}$ Journées Nationales Génie Côtier - Génie Civil}

Les Sables d'Olonne, 22-25 juin 2010

Following this procedure, the results of the stability analysis for Model A (Test 09051802) are given in figure 26a, showing that transient liquefaction indeed occurred around PT Layer 4 for $\mathrm{H}=1.4 \mathrm{~m}, \mathrm{~T}=5 \mathrm{~s}$ and $\mathrm{h}=3,9 \mathrm{~m}$.

A comparison with the stability analysis of Model B for the same regular wave test (figure 26b) illustrates why Model B did not fail. In fact, the effective stress $\sigma^{6}$ around PT Layer 4 droped to a very low level ( $\sigma^{\prime}=0.43 \mathrm{kN} / \mathrm{m}^{2}$ ) which is not far from the failure level.

A comparison of the stability of both Models A and B from a previous test with similar wave height and a shorter period $(\mathrm{H}=1.4 \mathrm{~m}, \mathrm{~T}=4 \mathrm{~s}$ and $\mathrm{h}=3.70 \mathrm{~m})$ have also shown why none of models A and B failed (see results in OUMERACI et al., 2009c).

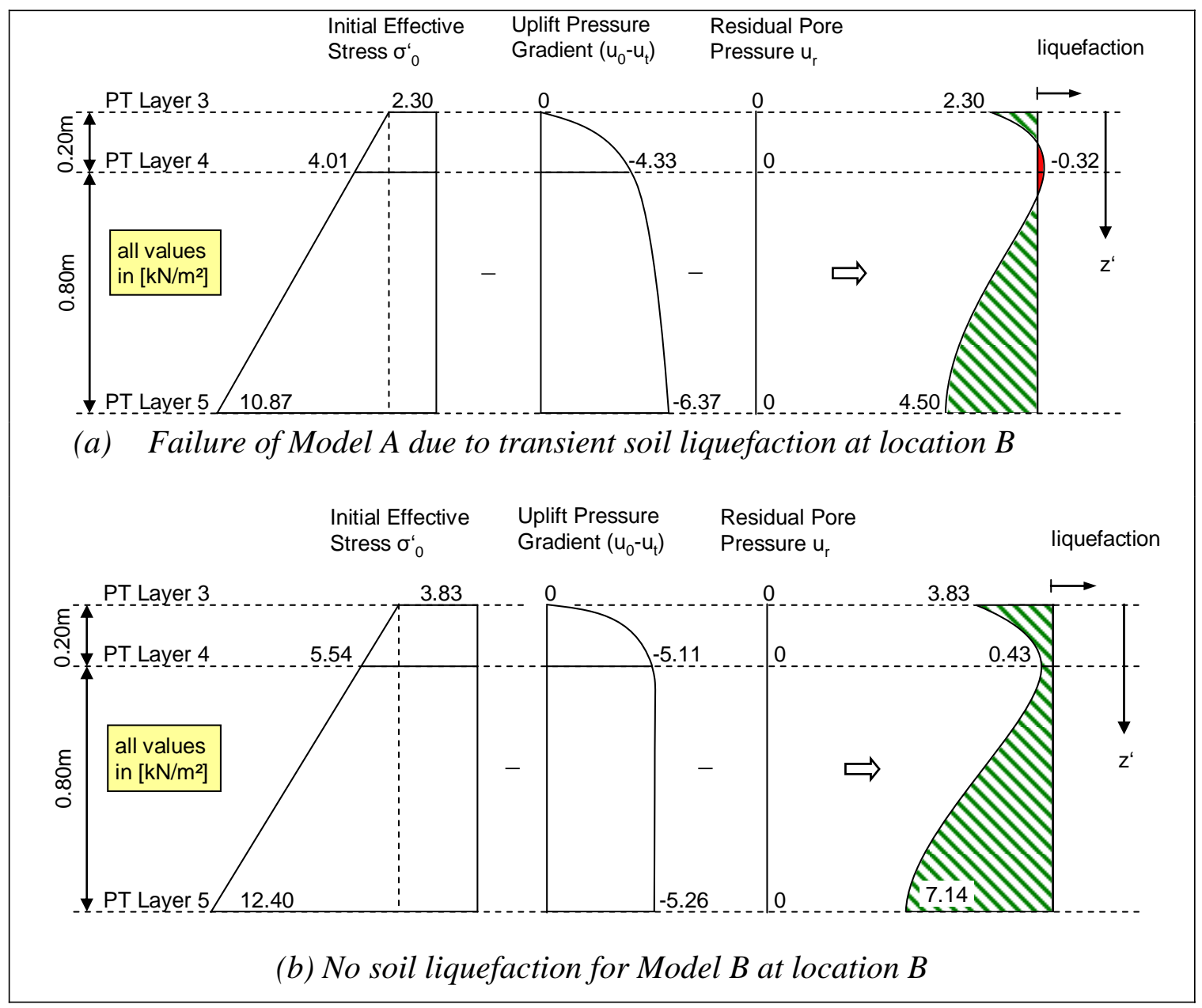

Figure. 26. Comparative stability analysis for Model A and Model B under the same wave conditions (Test 09051802 with $H=1.4 \mathrm{~m}, T=5 \mathrm{~s}, h=3.90 \mathrm{~m}$ ).

\section{Concluding Remarks and Outlook}

The results have confirmed the advantages of ELASTOCOAST revetments as compared to their conventional counterparts. In fact, due to the high porosity of ELASTOCOAST 
about 25\% lower defence structures with lower wave reflection might result as compared for instance to smooth impermeable revetments. Due to both high porosity and durable bonding of ELASTOCOAST, a substantially smaller revetment thickness would be required to resist the design wave loads. These advantages will remain, unless a substantial clogging is expected during life time.

Both impact and non-impact loads can be well described by the surf similarity parameter and the incident wave height. Although the impact pressure due to plunging breakers on the revetment can reach more than 6 times the pressure head of the incident significant wave height, it has been shown that the largest flexural deformations (bending) of the ELASTOCOAST revetment are rather caused by non-impact loads. Moreover, the impact pressures are substantially damped when transmitted just beneath the revetment in contrast to the quasi-static (non-impact) load which undergoes only a very slight damping (practically negligible). However, for both impact and non-impact loads, it is reasonable for design purpose to assume that the wave-induced pressures on and just beneath the revetment occur simultaneously as long as the porosity of the revetment is maintained (no substantial clogging).

Regarding the response of the sand core beneath the revetment to both impact and nonimpact load, the results show that the transient pore pressure in the upper sand layers may be crucial for the stability (transient soil liquefaction), if no sufficient burden resulting from the weight of both revetment and gravel filter is provided to generate the initial effective vertical stress required to resist against the upward directed pore pressure gradient. In fact, only the upper sand layers seem to be critical as the transient pore pressure for both impact and non impact loads are rapidly (exponentially) damped in deeper layers. Moreover, irrespective of the type of wave loads, the transient pore pressure in the sand generally exhibits a quasi-static character- even for impact loads.

Overall, the results have substantially contributed to improve the understanding of the physical processes involved in the wave-structure-foundation interaction, and based on this understanding to develop prediction formulae for the wave loading and the hydraulic performance of bonded permeable revetments which can be used in the design practice. Nevertheless, further research is still needed (i) to further improve the understanding and the prediction of the stepwise failure of the subsoil, (ii) to achieve a more precise coupling in time of the wave load on and just beneath the revetment for different porosities of the revetment during life time (clogging effect), and (iii) to better understand the coupling of the flexural deformations (bending) of the revetment and the failure mechanisms in the underlying sand core. For this purpose, a numerical model system, well-calibrated by the experimental data of the present study, would be required. Ideally, such a system should consist of (i) a CFD-model capable of describing the wave field in front of the porous slope structure, the detailed external flow on, in and just beneath the revetment, as well as the coupled internal flow in the underlying filter layer and sand core, and (ii) a CSD-model capable of describing the bending 
deformations and stresses in the revetment as well as the pore pressure and the effective stresses in the sand core beneath the revetment.

\section{Acknowledgements}

The financial support by BASF-Elastogran GmbH for this FZK-Project is gratefully acknowledged. The support for preparation and performance of the experiments by the GWK team of the Coastal Research Centre (FZK), particularly including Mr. Matthias Kudella and Dr. Stefan Schimmels is also acknowledged.

\section{References}

EUROTOP (2007). European Overtopping Manual. Pullen, T.; Allsop, N.W.H.; Bruce, T.; Kortenhaus, A.; Schüttrumpf, H.; Van der Meer, J.W.; Kuratorium für Forschung im Küsteningenieurwesen: Die Küste, Heft 73, [URL http://www.overtoppingmanual.com ]

KLEIN BRETELER M. (2007). Validatie van GOLKLAP. Report H4134 (in Dutch)

LOCK M. (2008). Early colonization of littoral communities on polyurethane coated substrates : a field and laboratory study. Arcadis Report, Hoofddorp, The Netherlands, $36 \mathrm{p}$.

MUTTRAY M. (2001). Wellenbewegung an und in einem geschütteten Wellenbrecher Laborexperimente im Großmaßstab und theoretische Untersuchungen. Braunschweig, Germany: Mitteilungen aus dem Leichtweiß-Institut für Wasserbau der Technischen Universität Braunschweig, Heft 148, S. 1-304. (in German), [URL http://opus.tubs.de/opus/volltexte/2001/203/pdf/muttraydiss.pdf ]

OUMERACI H., KUDELLA M., STAAL T. (2009a). Pre-design and preparatory works for the large-scale model tests on ELASTOCOAST revetment in GWK. Berichte Leichtweiß-Institut für Wasserbau, Technische Universität Braunschweig, Nr. 986, Braunschweig, Germany.

OUMERACI H., KUDELLA M., STAAL T. (2009b): Failure of the Elastocoast revetment during the large-scale model tests in GWK. Berichte Leichtweiß-Institut für Wasserbau, Technische Universität Braunschweig, Nr. 987, Braunschweig, Germany. OUMERACI H., STAAL T., PFÖRTNER S., LUDWIGS G., KUDELLA M. (2009c). Hydraulic performance, wave loads and response of Elastocoast revetments and their foundation- A large scale model study. Final Report Berichte Leichtweiß-Institut für Wasserbau, Technische Universität Braunschweig, Nr. 988, Braunschweig, Germany, $176 \mathrm{p}+$ Annexes.

OUMERACI H., MUTTRAY M. (2001). Bemessungswellenparameter vor Strukturen mit verschiedenen Reflexionseigenschaften. Abschlussbericht DFG-Projekt, OU 1/3-3, Braunschweig, Germany, 93 p. (in German) 
Thème 5 - Ouvrages portuaires, côtiers et offshore

PILARCZYK K.W., KLEIN BRETELER M., BEZUIJEN A. (1995). Wave forces and structural response of placed block revetments on inclined structures. In: Demirbilek, Z. and Kobayashi, N. (eds.): Wave forces on inclined and vertical structures, New York, USA, pp 52-87.

SCHÜTTRUMPF H. (2001). Hydrodynamische Belastung der Binnenböschung von Seedeichen durch Wellenüberlauf. Ph.D. thesis, Dissertation, Fachbereich Bauingenieurwesen, Leichtweiß-Institut für Wasserbau, Technische Universität Braunschweig , Braunschweig, Germany (in German), [URL http://www.biblio.tubs.de/ediss/data/20010703a/20010703a.html ]

SEELIG W.N. (1983). Wave reflection from coastal structures. Proceedings of Coastal Structures 1983, American Society of Civil Engineers (ASCE), pp 961-973.

USACE (2002). Coastal Engineering Manual. Engineer Manual Part-IV, 1110-2-1100, US Army Corps of Engineers, Washington D.C., USA.

ZANUTTIGH B., VAN DER MEER J.W. (2006). Wave reflection from coastal structures. Proceedings 30th International Conference Coastal Engineering (ICCE), ASCE, San Diego, USA, pp 4337-4349. 